Review

\title{
Four-Dimensional (Bio-)printing: A Review on Stimuli-Responsive Mechanisms and Their Biomedical Suitability
}

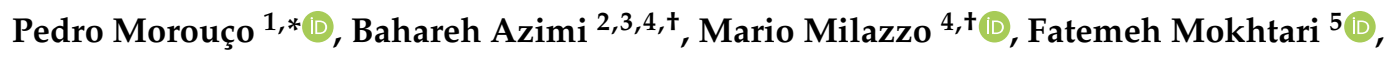 \\ Cristiana Fernandes ${ }^{1}$, Diana Reis ${ }^{6}$ and Serena Danti ${ }^{3,4, *(D)}$ \\ 1 Polytechnic of Leiria, 2400 Leiria, Portugal; cristiana.fernandes@ipleiria.pt \\ 2 Interuniversity National Consortiums of Materials Science and Technology (INSTM), 50121 Firenze, FL, Italy; \\ b.azimi@ing.unipi.it \\ 3 Department of Civil and Industrial Engineering, University of Pisa, 56126 Pisa, Italy \\ 4 Department of Civil and Environmental Engineering, Massachusetts Institute of Technology, \\ Cambridge, MA 02142, USA; milazzo@mit.edu \\ 5 Intelligent Polymer Research Institute, University of Wollongong, Wollongong, NSW 2500, Australia; \\ fm129@uowmail.edu.au \\ 6 Research and Development Department, Iber-Oleff, 3500 Pombal, Portugal; diana.nunesreis@gmail.com \\ * Correspondence: pedro.morouco@ipleiria.pt (P.M.); serena.danti@unipi.it (S.D.) \\ + These authors contributed equally to this work.
}

Received: 24 October 2020; Accepted: 17 December 2020; Published: 21 December 2020

check for updates

\begin{abstract}
The applications of tissue engineered constructs have witnessed great advances in the last few years, as advanced fabrication techniques have enabled promising approaches to develop structures and devices for biomedical uses. (Bio-)printing, including both plain material and cell/material printing, offers remarkable advantages and versatility to produce multilateral and cell-laden tissue constructs; however, it has often revealed to be insufficient to fulfill clinical needs. Indeed, three-dimensional (3D) (bio-)printing does not provide one critical element, fundamental to mimic native live tissues, i.e., the ability to change shape/properties with time to respond to microenvironmental stimuli in a personalized manner. This capability is in charge of the so-called "smart materials"; thus, 3D (bio-)printing these biomaterials is a possible way to reach four-dimensional (4D) (bio-)printing. We present a comprehensive review on stimuli-responsive materials to produce scaffolds and constructs via additive manufacturing techniques, aiming to obtain constructs that closely mimic the dynamics of native tissues. Our work deploys the advantages and drawbacks of the mechanisms used to produce stimuli-responsive constructs, using a classification based on the target stimulus: humidity, temperature, electricity, magnetism, light, $\mathrm{pH}$, among others. A deep understanding of biomaterial properties, the scaffolding technologies, and the implant site microenvironment would help the design of innovative devices suitable and valuable for many biomedical applications.
\end{abstract}

Keywords: additive manufacturing; tissue engineering; smart materials; hydrogels; biofabrication

\section{Introduction}

The main scope of tissue engineering (TE) is defined as the set of processes to develop biological structures that are able to restore, maintain, or even improve the function of tissues and/or organs [1]. Aiming to meet this challenging goal, multidisciplinary teams are required to work together in the fields of materials engineering and life sciences [2], to successfully employ scaffolds, growth factors, and cells, which represent the widely famous three pillars of TE. Initially, devices were mostly produced from 
bioinert materials, aiming to achieve adequate mechanical properties, inducing minimal responses from the host tissues. Then, bioengineered constructs were designed to provoke planned reactions at the implant site and follow a certain degradation rate. More recently, there has been emergent research on using smart materials to support and stimulate a better-mimicking tissue with high multicellular functionality [3-6].

Three-dimensional (3D) printing has appeared as a useful technique for TE scaffolding to develop constructs with high control over structure geometry and architecture [7,8]. Its first appearance was reported in 1986 by Hull et al., who used a novel technique called stereolithography [9], able to fabricate 3D structures by curing a resin with a UV source in a layer-by-layer fashion. Throughout the years, several other 3D printing techniques have been developed (Figure 1), e.g., fused deposition modeling [10], selective laser melting [11], and selective laser sintering [12]. All of these share a great advantage over conventional scaffolding techniques, namely, the ability to use computer assisted design - computer assisted manufacturing (CAD-CAM) to customize constructs, and obtain replacements with topologies optimized by using medical imaging approaches $[13,14]$. However, conventional 3D matrices have revealed not to be the optimal approach for a number of clinical needs, e.g., tissue defects that change faster than tissue healing, regenerative processes that could be stimulated by electrical or mechanical inputs, body environments in which physicochemical conditions, such $\mathrm{pH}$ and temperature, may change over time.

By including the capability of stimuli responsiveness, four-dimensional (4D) printing has emerged as an intriguing technology able to induce planned changes of the constructs (e.g., shape, stiffness) when triggered by a certain external stimulus $[15,16]$, thus showing the potential of bridging the gap between the laboratory constructs and native human tissues. Bioprinting is a printing technology that prints cells together with the biomaterial, usually a hydrogel, known as a bioink [17].

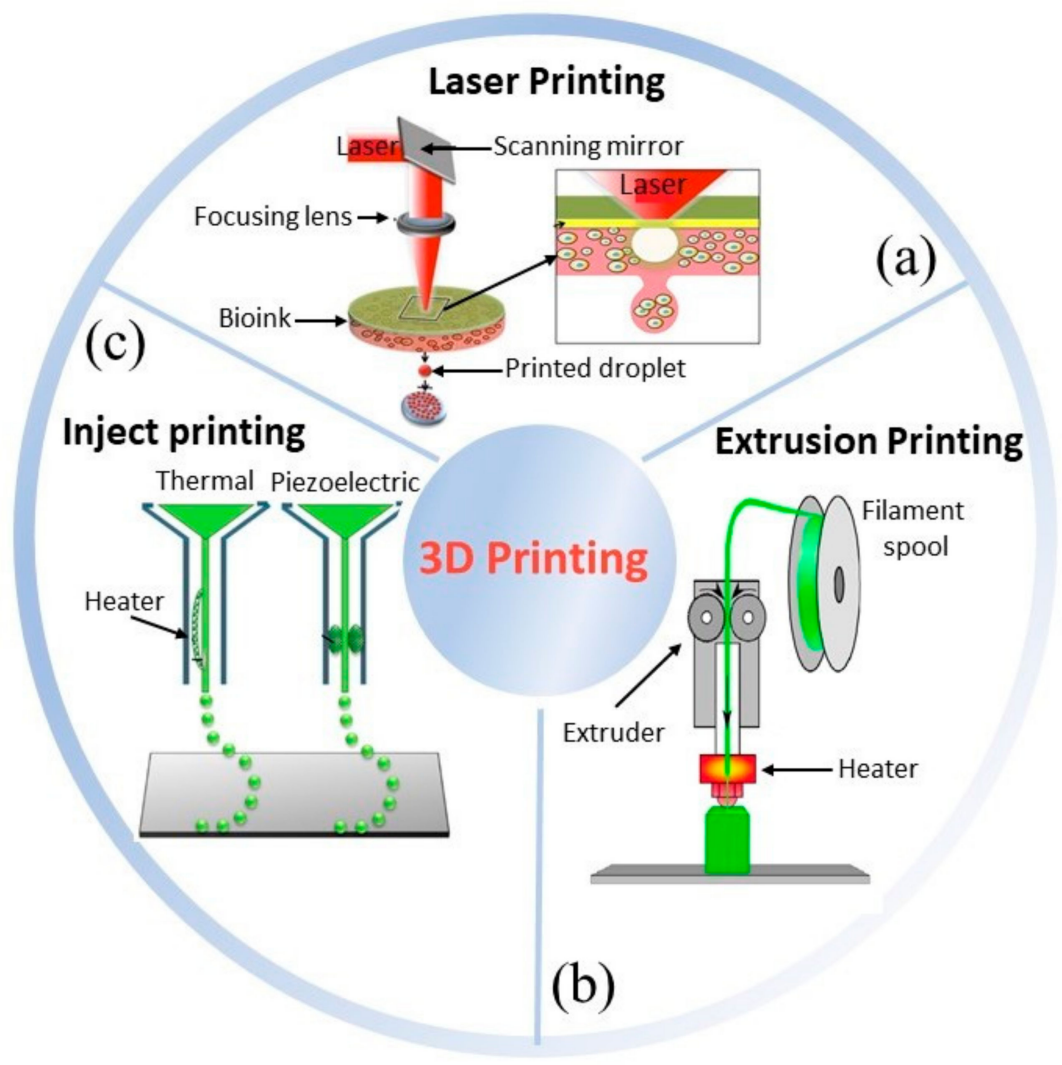

Figure 1. Three main bioprinting technologies: (a) laser [18], (b) extrusion [19], (c) inject printing [20]. Parts of the figure are reprinted from [18-20]—open access under Creative Commons CC BY 4.0 license. 
Smart biomaterials are at the basis of $4 \mathrm{D}$ printing, which, for biomedical applications, may also include printed live cells, thus being defined "bio"-printing [21]. Such materials can change shape or properties (e.g., stiffness, color, texture, transparency, energy transfer/conversion, volume) under the influence of external stimuli. Therefore, a clever use of such materials will result in 3D-built scaffolds that can adapt their features to specific applications [22,23]. As an innovative field, 4D (bio-)printing is suggested to be a promising tool to obtain effective TE therapies in a large number of clinical applications [24]. In the present review, the latest advances in $4 \mathrm{D}$ printing of biomaterials are described, by specifically examining the stimuli-responsive mechanisms and their biomedical suitability. $4 \mathrm{D}$ (bio-)printing is an emerging topic of investigation and novel points of view are necessary to build up a critical and instructive knowledge in this field [25].

\section{Four-Dimensional (Bio-)printing}

$4 \mathrm{D}$ printing is the latest advancement in the advanced manufacturing field [15]. It was initially defined as a procedure where the shape, properties, or functionality of a 3D printed structure can change according to time and/or stimuli (Figure 2) [26]. The foundational works were developed at the Massachusetts Institute of Technology (MIT), by considering time as the fourth dimension [27]. Given this, 4D (bio-)printing indicates that for the transition, over time, the 3D printed biocompatible materials may incorporate live cells by using bioinks [24]. Thereafter, sequential approaches have been applied to the concept of $4 \mathrm{D}$ (bio-)printing, according to the identified stimuli concurring to defined biomedical applications. The first approach to $4 \mathrm{D}$ printing closely followed the MIT concept, in which the material (e.g., smart biopolymer or responsive hydrogel), under the desired stimulus, folds in a predefined 3D configuration, and cells or tissues simply follow the substrate fold and form the desired shape. The second approach is the "in vivo $4 \mathrm{D}$ bioprinting" in which a 3D polymer is printed, acting as a medical device, initially implanted to accommodate tissue or organ growth after the postsurgical period. When the tissue or organ gets stronger, the scaffold degrades gradually, preferably in a controlled manner, and is absorbed by the body. In this approach, tissue growth can be viewed as a leading stimulus. However, considering 3D printed scaffolds under the $4 \mathrm{D}$ printing umbrella because of their biodegradation property (i.e., controlled biodegradation as a shape change over time), is utmost controversial [25].

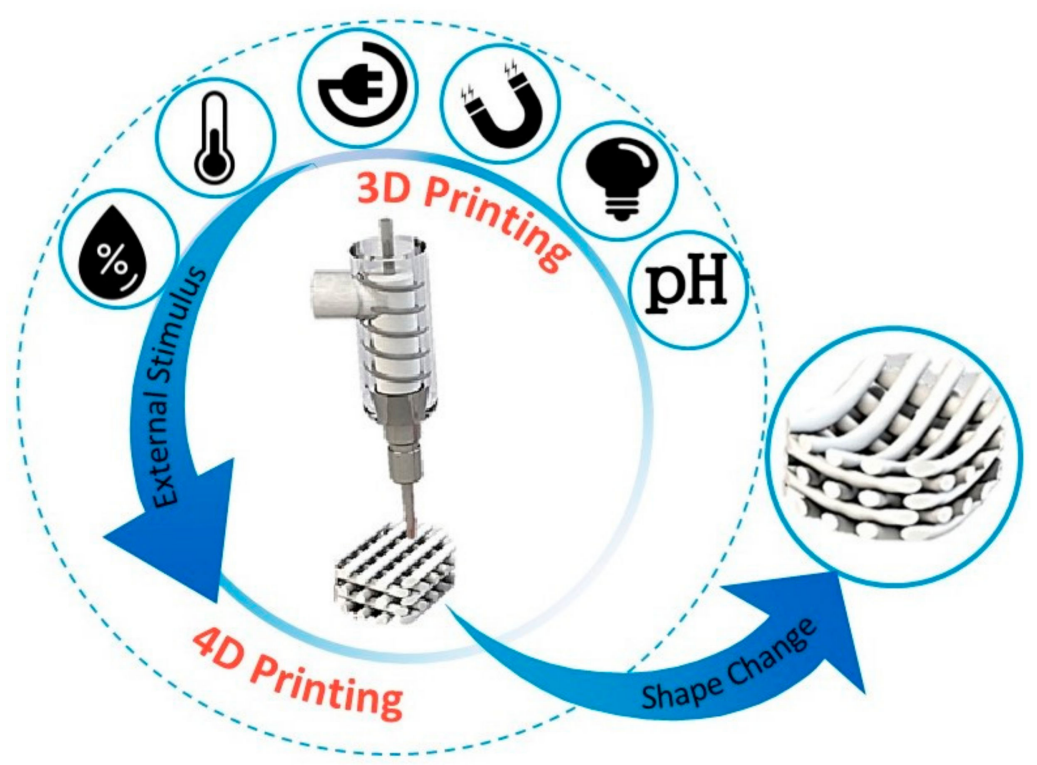

Figure 2. Illustrative diagram representing addition of a predesigned stimulus to promote a desired change at the construct. [Original image from the authors]. 
An et al. proposed a definition for $4 \mathrm{D}$ bioprinting, referring to groups of programmable self-assembling, self-folding, or self-accommodating technologies, which include three main defined or essential components: (i) man-made and not nature-made programmable design, (ii) two dimensional (2D) or 3D bioprinting process, and (iii) postprinting programmable evolution of bioprinted constructs that can be driven by cells or biomaterials and triggered by external signals [27].

The main advantageous characteristics of $4 \mathrm{D}$ bioprinting include additional degrees of freedom in terms of design, high precision cell placement, and the ability to produce tissues with adequate cellular density [15]. Many 3D printed scaffolds with programmable biodegradation fit within this definition, but are beyond the topic of this review. So far, a widely accepted definition of $4 \mathrm{D}$ printing is still missing, as from Moroni et al.: "Whether we are really witnessing 4D printing, a process that should be defined as a programmed temporal shape change occurring during the 3D manufacturing itself, or not, is still to be clarified in the field" [28]. In this scenario, many researchers are investigating different materials and approaches enabling controllable shape/property changes upon different stimuli and timeframes, which are suggested in this review under the name of $4 \mathrm{D}$ (bio-)printing.

A category that naturally suits the $4 \mathrm{D}$ (bio-)printing concept is the printing of smart hydrogels [29]. Hydrogels are polymeric networks able to form water-swollen structures thanks to different types of forces between the polymer chains, leading to semi-crystalline or amorphous materials [14,30,31]. Smart hydrogels are able to respond to a desired stimulus (e.g., shear stress, electricity, ionic force, light, magnetic field, $\mathrm{pH}$, temperature). The interest in developing smart hydrogels has been increasing within the last years, as they should be able to provide remarkable characteristics, such as shape memory, self-healing and controllable sol-gel transition. Thus, being able to use the advantages of 3D (bio-)printing (e.g., customization), it is possible to improve the features of hydrogels by promoting self-weldability or self-unfoldability according to an external stimulus. As discussed in literature, both these characteristics, as $4 \mathrm{D}$ bio-origami hydrogels, may significantly contribute to achieve functional tissues [15], and to the fabrication of engineered tissues, such as liver [32] and heart [33], making a major breakthrough in the area of TE [24,34]. Extensive research has been carried out on the development of smart hydrogels. From a mechanical standpoint, hydrogels can show bare elastic up to viscous-elastic behavior, because of crosslinking type and density. To characterize hydrogels, Young's modulus (E), storage modulus $\left(G^{\prime}\right)$, and loss modulus $\left(G^{\prime \prime}\right)$, as well as other hydrogel-specific parameters, such as mesh size, polymer volume fraction in the swollen state, and average molecular weight between crosslinks, should be evaluated. Since water does act as a plasticizer among the polymer chains, hydrogels used in their swollen state, as in TE, are well above their glass transition temperature $\left(\mathrm{T}_{\mathrm{g}}\right)$ and show viscoelasticity under loading conditions. For example, appropriate mechanical stimulation and biomechanical signals are key factors in tendon/ligament $(\mathrm{T} / \mathrm{L})$ engineering. As the native $\mathrm{T} / \mathrm{L}$ is able to respond to mechanical forces by changing structure, composition, and mechanical properties [35-37], smart hydrogels obtained via $4 \mathrm{D}$ printing cold help to achieve such a critical goal. Typical mechanical values of hydrogels (e.g., $\approx 0.1$ MPa Young's moduli) are usually far from satisfying T/L mechanics (i.e., 1.2-1.8 GPa tensile modulus) that can be achieved only by high modulus chemically crosslinked hydrogels [38,39]. Moreover, transition zones of $\mathrm{T} / \mathrm{L}$ into muscle or bone need a gradient of properties capable of responding to personalized tissue mechanics.

As the field of $4 \mathrm{D}$ (bio-)printing continues to grow, in the next years it is expected to rapidly expand across fields, including regenerative medicine, robotics, and medical devices [16]. In the following sections, we focus on smart hydrogels and their applications in $4 \mathrm{D}$ (bio-)printing.

\section{Stimuli-Responsive Mechanisms: Avenues for 4D (Bio-)printing}

The main features that smart materials exhibit are self-adaptability, self-sensing, shape-memory, responsiveness, multifunctionality, and self-repair. These characteristics determine their after-printing properties in response to external stimuli, leveraging several promising applications $[15,40]$. However, some reviews on stimuli-responsive materials have already been provided in other fields $[5,26,41]$, it is now highly relevant to clarify their suitability for biomedical applications. Indeed, the functionality 
changes of a 4D bioconstruct critically depend on the given stimulus and material choice that are selected based on the desired application [42]. Polymers able to react to stimuli undergo changes in their properties, like size or shape, as well as permeability, mechanical, surface, optical, and electrical properties after applications of physical stimuli, such as temperature, light, electric, mechanic, and magnetic fields, and they will be described in the next sections. The possibility of 3D (bio-)printing smart materials seems to factually enable $4 \mathrm{D}$ (bio-)printing, even though future definitions in this field could better clarify any specific circumstances.

As previously mentioned, stimuli-responsive hydrogels belong to the category of smart materials, as they can respond to various environmental factors [6]. Smart hydrogels are able to change their network structure, mechanical strength, permeability, and swelling behavior in response to stimuli. Interestingly, many stimuli-responsive hydrogels show a fully reversible change, being significantly attractive for the biomedical domains [43]. The major advantages of smart hydrogels are a high-water content that closely mimics the environment of the natural tissues and promotes a more efficient mass transport than those occurring in other materials. Furthermore, smart hydrogels have unique characteristics such as sol-gel transition, shape memory, or self-healing, which are highly relevant for bioprinting medical devices [29]. A successful bioprinted hydrogel construct should have the following properties: (i) printability, which is related to proper viscosity, short response, transition time, and a suitable sol-gel transition stimulus [44,45]; (ii) biocompatibility, including biodegradability, ability to withstand cell-cell and cell-matrix connections and absence of toxicity; (iii) mechanical properties, identical to the target tissue regarding stiffness, elasticity, and strength, and (iv) shape and structure, as the print should exhibit high structural similarities to the natural tissue. Therefore, these hydrogels can be printed via different techniques [46]. For instance, extrusion usually requires high viscosity and shear-thinning property, while an inkjet-based technique requires low viscosity of the material with low sol-gel response and transition time $[29,45]$.

Since hydrogel properties can be manipulated through chemistry and crosslinking [14], an additional aspect that researchers should consider is the effectiveness of computational modeling to predict the material responses without time-consuming experimental activities. Accordingly, theoretical and mathematical models have been developed, achieving an optimal association between the structure of the material, the desired final shape, the properties of the material, and the intended stimuli [26].

\subsection{Humidity-Responsive Materials}

As water abundant in nature, humidity-sensitive polymers are receiving much consideration in the health and personal comfort domains, as well as for many industrial and technological applications [47]. In the TE field, the humidity-responsiveness is the property that refers to different levels of temporal/spatial swelling deformation that can be induced in a scaffold [24]. However, they are still practical challenges for extensive use of such materials due to their responsive times together with complicated control actuation, mostly provoked by the slow kinetics of water diffusion. Table 1 reports examples of $4 \mathrm{D}$ smart material in this field. 
Table 1. Overview of the experiments on $4 \mathrm{D}$ (bio-)printing and other manufacturing approaches using humidity as a predefined stimulus.

\begin{tabular}{|c|c|c|c|}
\hline Material(s) & Mechanism(s) & Application(s) & Ref. \\
\hline PEG-PCAD@AG & Humidity & $\begin{array}{l}\text { For applications that require } \\
\text { contactless actuation in response to } \\
\text { the day-night rhythm of } \\
\text { atmospheric humidity }\end{array}$ & [48] \\
\hline PEG-PCL-CNC & Humidity & $\begin{array}{c}\text { Medical applications such as smart } \\
\text { sutures, vascular stents, esophageal } \\
\text { stents, tissue engineering scaffolds, } \\
\text { and drug delivery }\end{array}$ & [49] \\
\hline $\begin{array}{l}\text { Liquid-crystalline (LC) polymer } \\
\text { networks activated with an } \\
\text { alkaline solution }\end{array}$ & Humidity & $\begin{array}{l}\text { Humidity-responsive actuators for } \\
\text { application in smart textiles }\end{array}$ & {$[47,50]$} \\
\hline $\begin{array}{l}\text { Poly(ethylene glycol) diacrylate } \\
\text { hydrogel }\end{array}$ & Humidity & $\begin{array}{l}\text { Sensors, actuators, or construction } \\
\text { of soft robots, artificial muscles, } \\
\text { molecular motors, programmable } \\
\text { origami, and energy generators }\end{array}$ & {$[51,52]$} \\
\hline Polyethylene glycol & Humidity & Tissue engineering & [53] \\
\hline $\begin{array}{l}\text { Combining polypyrrole and } \\
\text { polyol-borate }\end{array}$ & Humidity & Actuator and generator & [54] \\
\hline Cellulose stearoyl esters (CSEs) & Humidity, temperature & $\begin{array}{c}\text { Sensors, actuators, or construction } \\
\text { of soft robots }\end{array}$ & [55] \\
\hline $\begin{array}{l}\text { Poly(3,4-ethylenedioxythiophene): } \\
\text { polystyrene sulfonate and } \\
\text { poly(vinylidene fluoride) } \\
\text { PEDOT:PSS/PVDF composite }\end{array}$ & Humidity & Actuator and generator & [56] \\
\hline $\begin{array}{c}\text { Printing a layer of hydrophilic } \\
\text { material over a layer of } \\
\text { rigid material }\end{array}$ & Humidity & Self-evolving structure & [57] \\
\hline $\begin{array}{l}\text { Hydrogel composite ink } \\
\text { composed of stiff cellulose fibrils } \\
\text { embedded in a soft } \\
\text { acrylamide matrix }\end{array}$ & Humidity & $\begin{array}{c}\text { Tissue engineering, biomedical } \\
\text { devices, soft } \\
\text { robotics }\end{array}$ & {$[58]$} \\
\hline $\begin{array}{c}\text { Poly(ionic liquid)s (PILs), } \\
\text { poly(1-methyl } \\
\text { azobenzene-3-vinylimidazolium } \\
\text { bromide) ([PMAzoVIm]Br) and } \\
\text { poly(acrylic acid) (PAA) }\end{array}$ & Humidity and light & Selective dye adsorption & [59] \\
\hline
\end{tabular}

One controversial material, due to carcinogenic properties, is based on poly(ethylene glycol) (PEG)—combining azobenzene derivative (PCAD) with agarose (AG), forming PCAD@AG [16,48]. As azobenzene is classified as B2 (probable human carcinogen) according to the National Centre for Environmental Assessment, this material is likely not to be adequate for humans, even if there is no carcinogenicity data in humans [60]. Indeed, when studied in both genders of mice, azobenzene (dietary administration) had negative effects inducing invasive sarcomas in the spleen and in other abdominal organs afterward. In addition, it is genotoxic and under acidic conditions in the human stomach it may be converted to benzidine [32]. Either way, researchers have been studying its properties as agarose (fast water absorption material but low desorption) combined with PCAD can decrease the absorption rate and increase desorption, establishing a moisture responsive system [16]. When the PCAD@AG film is in contact with moisture, it quickly absorbs water and swells, folding up. This folding can be guided with a moisture gradient; PCAD@AG folds or coils according to the expansion on the contact 
side produced by the water absorption. In contrast, if placed on a wet filter paper, its membrane will rapidly coil and unwind in successive reverse directions, rapidly moving on the paper [48].

Polymers with shape memory induced by water have received relevant consideration. Liu et al. [49] developed polymers presenting promising potential for biomedical actuation, such as self-tightening sutures, or self-retractable and removable stents. They developed a synthetic network of polymer nanocomposites capable of responding to water stimulation through the chemical crosslinking of cellulose nanocrystals (CNC) with poly( $\varepsilon$-caprolactone) (PCL) and (PEG). In particular, the PEG [60]-PCL [40]-CNC [10] nanocomposite was found to have excellent water-induced shape-memory effects at $37^{\circ} \mathrm{C}$ (Figure 3a).
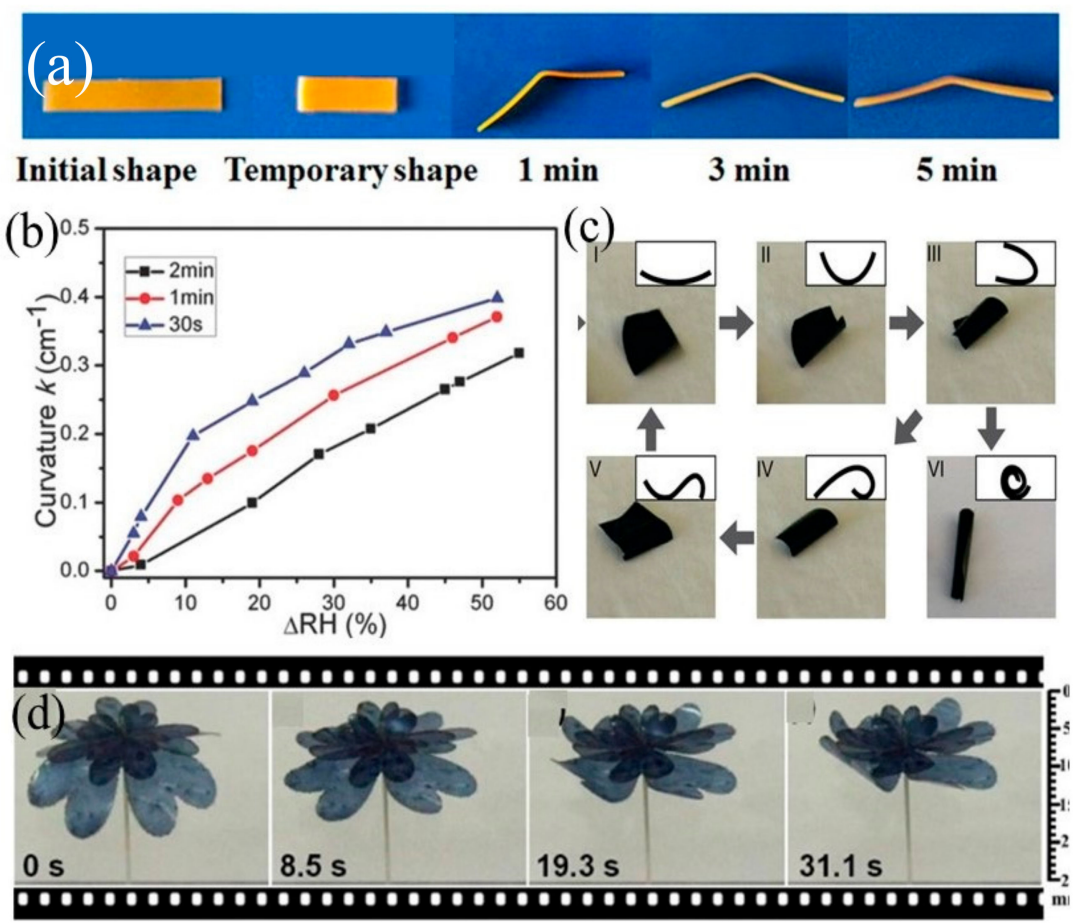

Figure 3. Humidity-responsive of smart materials: (a) Water-responsive shape-memory process of the PEG-PCL-CNC nanocomposites in water at $37^{\circ} \mathrm{C}$. Reprinted with permission [49] (C) 2020 American Chemical Society. (b) Dependent curve of bending curvature on the variation of relative humidity $(\triangle \mathrm{RH})$ for PEG-DA hydrogel films with different exposure time. Reprinted with permission [52] C) 2020 John Wiley and Sons. (c) Locomotion of a PEE-PPy film on a moist substrate. One flipping cycle refers to a motion process starting from stage I through stage $\mathrm{V}$ and back to stage I. Reprinted with permission [54] (C) 2020 The American Association for the Advancement of Science. (d) Biomimetic dragonflies with moisture response fabricated by PEDOT: PSS/PVDF composite film. Reprinted with permission [56] (C) 2020 Elsevier.

Both PCL and PEG can be applied in medicine since they are biocompatible and biodegradable materials making them good candidates for applications as biomaterials, as already mentioned in the literature and approved by the U.S. Food and Drug Administration [61]. Less is known on CNC biocompatibility, as their use for biomedical purposes is recent. However, cytotoxicity tests have confirmed that nanocomposites have very good cytocompatibility, suggesting that they can be used in biomedical applications such as vascular stents, esophageal stents, smart sutures, tissue engineering scaffolds, and drug delivery [49]. PEG and PEG-diacrylate hydrogel are also able to respond to water stimulation and have been used as sensors and actuators, or in the construction of soft robots, artificial muscles, programmable origami, energy generators, and scaffolds for TE applications [51-53,62]. Figure $3 \mathrm{~b}$ shows the effects of different exposure times on the humidity response sensitivity of the PEG-DA hydrogel films. By increasing the variation of relative humidity $(\Delta \mathrm{RH})$, the bending curvature 
of the three films increased. Longer exposure time also led to an increased crosslinking density of the polymer networks, therefore under the same $\Delta \mathrm{RH}$, the film with longer exposure time had a smaller bending curvature [52]. Active origami are self-actuating structures, which are capable of folding and unfolding. By designing structures that can fold and occupy small spaces, origami can potentially provide suitable solutions for minimally invasive surgery. Another type of moisture-sensitive actuators is based on liquid-crystalline (LC) polymer networks. These have the ability to provide intricate anisotropic deformations, such as spiral ribbons, helicoids, and conic and anticonic forms. Usually, the control of the aimed deformations is based on the alignment and molecular order of the LC units, throughout the three dimensions of the polymer network [47]. Likewise, these networks activated with an alkaline solution can be used as humidity-responsive actuators for application in smart textiles. As a recent example, elastomeric, soft, water-swelling, shape-memory liquid-crystalline anisotropic hydrogels have been proposed as a novel biomaterial [50].

Some other compositions have been used as humidity-sensitive materials for different applications [54,56-59,63]; for example, the pentaerythritol ethoxylate-polypyrrole (PEE-PPy) film folded into a roll and remained static in a closed chamber saturated by water vapor. One locomotive cycle of the film composed of five different stages was formed (Figure 3c). Both sides of the film were equilibrating with water in the substrate and in the lower-humidity air during the five-step flipping process. Therefore, the water gradient between substrate and air led to the asymmetric deformation of the film that drove the film locomotion, with the cooperation of film gravity and friction with the substrate [54]. Wang et al. reported a simple and versatile method for preparing a moisture-responsive composite film combined poly(3,4-ethylenedioxythiophene): polystyrene sulfonate and poly(vinylidene fluoride) PEDOT:PSS/PVDF to act as double-layered actuator and generator with good moisture response (Figure 3d) [56]. Gladman et al. printed a composite hydrogel composed of stiff cellulose fibrils to manufacture plant-inspired architectures able to change shape when placed in water, yielding complex 3D morphologies [58].

\subsection{Temperature-Responsive Materials}

The medical interest in thermoresponsive materials relies on the fact that physiological temperature is constantly set around $37^{\circ} \mathrm{C}$ in humans, besides small variations due to pathologic conditions. As thermoresponsive materials change their properties at a predefined temperature, they can be handled and delivered to the human body in a different state (e.g., liquid), to finally change after implantation (e.g., solid). In addition to this, thermoresponsive materials can also provide a useful means of monitoring storage temperature of drugs and bioactive devices, as a prolonged time of exposure to high temperatures can affect their outcomes. In this view, new SU-8 nanofiber-based intelligent indicators for perishable supply chain aim to monitor both temperature and time of temperature change duration in order to ensure reliability of bioactive properties [64]. Furthermore, some diseases induce changes in body temperature that can be identified as a planned stimulus for temperature-sensitive polymers [65]. Temperature responsiveness is one of the most frequently studied mechanisms to obtain user-defined functionality [16], and the most used stimulus to deform bioprinted constructs [24,66-68].

Thermoresponsive materials may employ exogenous temperature changes as stimuli to achieve shape transformation. These materials can bend, shrink, or swell depending on temperature changes, as some polymers have the phase transition temperature similar to the physiological temperature [24]. The sensitivity to temperature is caused by the equilibrium between hydrophobic and hydrophilic segments, such as monomeric units or polymer blocks [69]; an upper critical solution temperature (UCST) or a lower critical solution temperature (LCST) can promote interactions between the polymer and the aqueous medium, providing the interruption of the electrostatic (intra- and intermolecular) and hydrophobic actions, which result in collapse or expansion of the polymeric chains [65]. By copolymerizing hydrophobic monomers or adapting the molecular weight of the polymer, LCST can be adjusted to the desired temperature. For instance, increasing the monomers along with a high molecular weight will promote a reduction of LSCT, whereas adding hydrophilic monomers (forming 
hydrogen bonds) with thermosensitive monomers will cause an increase of the LCST [69]. A number of temperature-sensitive polymers are reported in Table 2. A candidate material adequate for drug delivery or tissue regeneration is poly( $N$-isopropylacrylamide) (PNIPAAm), which can be composed with PCL and applied in cell encapsulation and/or release $[24,67,70]$. For example, star-like bilayer poly-(NIPAM-ABP) films remained undeformed at $\mathrm{T}>28^{\circ} \mathrm{C}$, but by decreasing the temperature below the cloud point of poly-(NIPAM-ABP), the arms of the bilayer started to bend (Figure 4a) [70]. Figure $4 \mathrm{~b}$ shows the shrinking process of hydrogel after being incubated at $40{ }^{\circ} \mathrm{C}$ water for $35 \mathrm{~s}$, which led to the formation of a tubelike gel reaching $\approx 80 \%$ of the shape change [71].

Among all thermoresponsive materials, PNIPAAm, which is composed of both hydrophilic amide (-CONH-) groups and hydrophobic isopropyl $\left[-\mathrm{CH}\left(\mathrm{CH}_{3}\right)_{2}\right]$ side chains, is the best known, as it exhibits a LCST around $32{ }^{\circ} \mathrm{C}$, has a sol state that can switch to gel state by approaching the body temperature $\left(37^{\circ} \mathrm{C}\right)$. This property makes PNIPAM a very good candidate for biomedical applications such as scaffolds for tissue engineering, drug carriers, and skin dressings for wound treatment [72]. Cytotoxicity tests have already been performed on PNIPAAm, and results showed low levels of toxicity for the cells $[73,74]$. A temperature-responsive hydrogel based on PNIPAAm-co-gelatin copolymer was used to produce hepatoma cell line (Hepa/8F5) spheroids, showing that, by virtue of the 3D cellular aggregation enabled by this copolymer, they possessed higher resistance to different drugs [75]. Having more reliable biomaterial-assisted 3D in vitro models is very useful for drug development and therapy screening in many research areas, including liver cancer [76,77]. The copolymer of PNIPAAm and N-tert-butylacrylamide (NtBAAm) have been used as delivery vehicles of an antimitotic agent to vascular smooth muscle cells [78]. Yang et al. synthesized different thermally responsive dendritic core-shell polymers based on dendritic poly(ether-amide) (DPEA), modified with carboxyl end-capped linear poly(N-isopropylacrylamide) (PNIPAAm-COOH) or both PNIPAAm-COOH and carboxyl end-capped methoxy polyethylene glycol (PEG-COOH), in different ratios for drug delivery applications [79]. Results demonstrated that all lower critical solution temperatures were higher than that of traditional linear PNIPAAm, or its copolymers.

In another attempt, colloidal suspensions of ceramic powder $\left(\mathrm{Al}_{2} \mathrm{O}_{3}\right)$ dispersed by thermosensitive dispersant poly(acrylicacid)-poly(N-isopropylacrylamide) (PAA-PNIPAM) were designed for tailoring the rheology of suspensions, which is an indispensable matter for 3D printing applications [68]. For poly(N-vinylcaprolactam) (PNVC), toxicity tests did not reveal any evidence of cytotoxicity, confirming that for short exposure time at the aimed temperature, the polymers can be considered nontoxic (Figure 4c) [80].

Similarly, poly(L-lactic acid) (PLLA)-PEG block copolymer showed biodegradability, good biocompatibility, and amphiphilic characteristics, thus providing the adequate requirements for biomedical usage [81]. Finally, it was observed that the copolymer of polyethylene oxide (PEO) and polypropilene oxide (PPO), namely PEO-PPO-PEO displayed low levels of toxicity, even with a high percentage of PEO [82]. The ability of triethoxysilane-capped PEO-PPO-PEO triblock to perform as matrices for drug delivery was also investigated [83].

Findings showed that crosslinked gels released drugs, e.g., metronidazole, at a much slower rate than pluronic F127 (PEO99-PPO67-PEO99). Accordingly, Cho et al. revealed a supreme potential of PLGA-b-PEG-b-PLGA thermogels to carry multidrugs for intraperitoneal (IP) chemotherapy in the cancer of peritoneal ovarian [84]. 

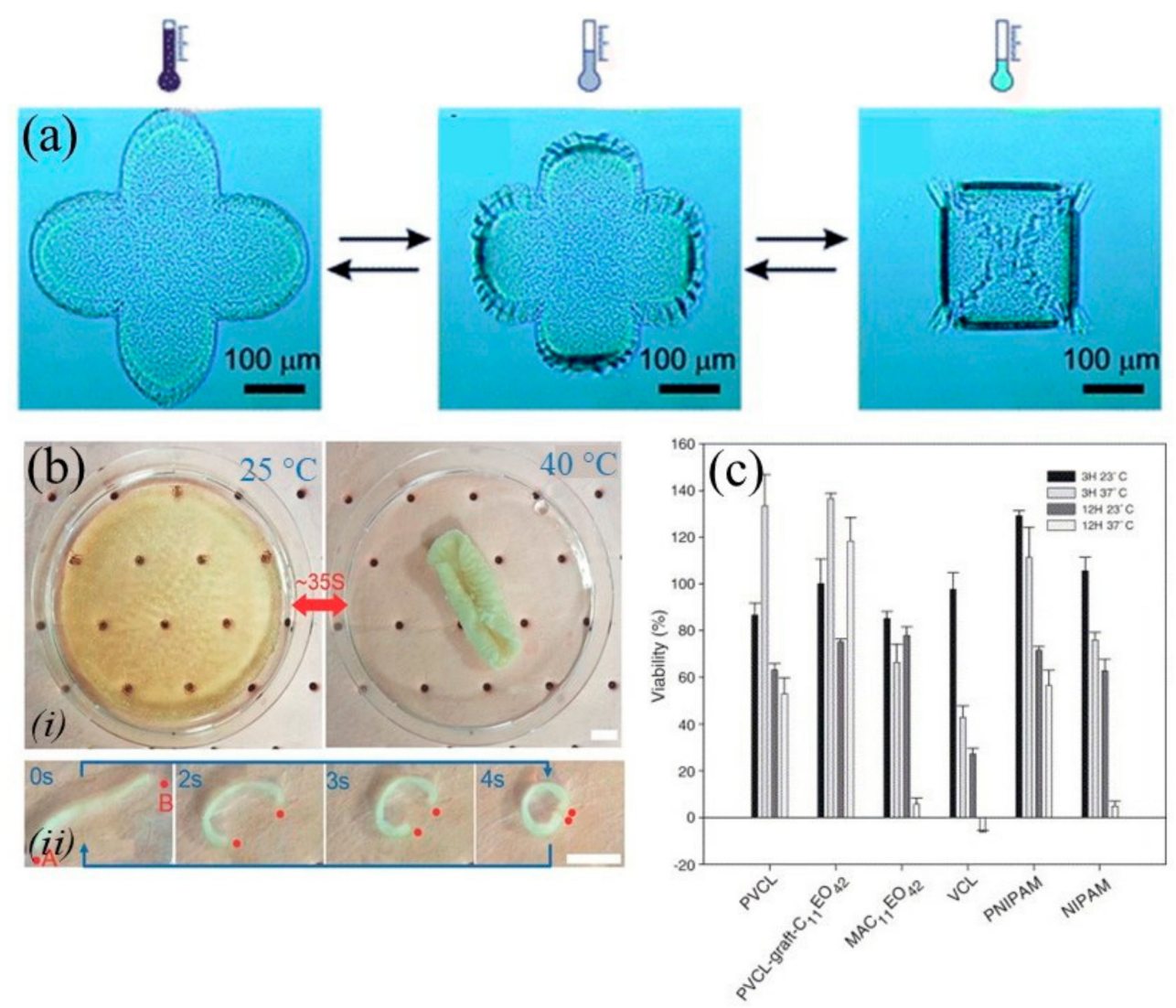

Figure 4. Temperature-responsive materials: (a) The polymer bilayer is undeformed at elevated temperatures when the poly-(NIPAM-ABP) layer is shrunk. Reprinted with permission [70] (C) 2020 The Royal Society of Chemistry. (b) Thermally triggered response of hydrogels: (i) Morphology of a gradient porous hydrogel at 25 and $40{ }^{\circ} \mathrm{C}$, (ii) Morphology and thermal responsive time of a gradient porous hydrogel strip after being put into $40{ }^{\circ} \mathrm{C} \mathrm{H}_{2} \mathrm{O}$. Reprinted with permission [71] (C) 2020 John Wiley and Sons. (c) Viability values for the thermosensitive polymers and monomers. Reprinted with permission [80] (C) 2020 Elsevier.

Table 2. Overview of the experiments on $4 \mathrm{D}$ (bio-)printing and other manufacturing approaches using temperature as a predefined stimulus.

\begin{tabular}{cccc}
\hline Material(s) & Mechanism(s) & Application(s) & Ref. \\
\hline $\begin{array}{c}\text { Poly(N-alkyl substituted } \\
\text { acrylamides) }\end{array}$ & Temperature & NA & {$[65]$} \\
\hline $\begin{array}{c}\text { Poly(N-isopropylacrylamide) } \\
\text { (PNIPAAm) }\end{array}$ & Temperature & $\begin{array}{c}\text { Drug delivery, tissue } \\
\text { regeneration, yeast cell } \\
\text { encapsulation, artificial } \\
\text { muscle, programmable } \\
\text { actuators }\end{array}$ & $\begin{array}{c}{[24,63,65,67,70,73,} \\
74,85-87]\end{array}$ \\
\hline $\begin{array}{c}\text { Poly(N-vinylalkylamides) } \\
\text { Poly(N-vinylcaprolactam) } \\
\text { (PNVC) }\end{array}$ & Temperature & NA & {$[65,79]$} \\
\hline $\begin{array}{c}\text { Copolymer of } \\
\text { N-isopropylacrylamide } \\
\text { (NiPAAm) and }\end{array}$ & Temperature & $\begin{array}{c}\text { Stabilization of proteases } \\
\text { and controlled drug } \\
\text { delivery }\end{array}$ & {$[80,88]$} \\
$\begin{array}{c}\text { N-tert-butylacrylamide } \\
\text { (NtBAAm) }\end{array}$ & Temperature & $\begin{array}{c}\text { Potential vehicles for } \\
\text { delivery of an antimitotic } \\
\text { agent to vascular smooth } \\
\text { muscle cells }\end{array}$ & {$[78]$} \\
\hline
\end{tabular}


Table 2. Cont.

\begin{tabular}{|c|c|c|c|}
\hline Material(s) & Mechanism(s) & Application(s) & Ref. \\
\hline $\begin{array}{l}\text { Poly(ether-amide) grafting with } \\
\text { PNIPAAm and PEG }\end{array}$ & Temperature & Controlled drug release & [79] \\
\hline $\begin{array}{l}\text { Poly(acrylic acid)-PNIPAAm } \\
\text { and ceramic powder }\left(\mathrm{Al}_{2} \mathrm{O}_{3}\right)\end{array}$ & Temperature & $\begin{array}{c}\text { Drug delivery and tissue } \\
\text { regeneration }\end{array}$ & [68] \\
\hline $\begin{array}{l}\text { Poly(t-lactic acid)-poly(ethylene } \\
\text { glycol) Poly(l-lactic acid) } \\
\text { (PLLA-PEG-PLLA) }\end{array}$ & Temperature & $\begin{array}{c}\text { Potential anticancer } \\
\text { drug carrier, drug } \\
\text { delivery }\end{array}$ & {$[65,89]$} \\
\hline $\begin{array}{l}\text { Poly(ethylene oxide)-poly } \\
\text { (propylene oxide)-poly } \\
\text { (ethylene oxide) } \\
\text { (PEO-PPO-PEO) }\end{array}$ & Temperature & Controlled drug delivery & {$[82,83,90]$} \\
\hline $\begin{array}{l}\text { Epoxy based UV curable shape } \\
\text { memory polymers (SMP) }\end{array}$ & Temperature & $\begin{array}{l}\text { Medical, civil, and } \\
\text { industrial }\end{array}$ & [91] \\
\hline $\begin{array}{l}\text { Poly-(D,L-lactide-co-glycolide)- } \\
\text { block-poly(ethylene glycol)- } \\
\text { block-poly-(D,L-lactide-co-glycolide) } \\
\text { (PLGA-b-PEG-b-PLGA) triblock } \\
\text { copolymer thermogels }\end{array}$ & Temperature & $\begin{array}{l}\text { Potential anticancer } \\
\text { drug carrier }\end{array}$ & [84] \\
\hline Methacrylate based copolymer & Temperature & Biomedical devices & [92] \\
\hline $\begin{array}{c}\text { (PNIPAAm; PCL); alumina } \\
\text { ceramics }\end{array}$ & Transition temperature & $\begin{array}{l}\text { Pharmaceutical } \\
\text { formulations, skeletal } \\
\text { muscle-like linear } \\
\text { actuation }\end{array}$ & {$[24,67,70]$} \\
\hline Methyl cellulose hydrogel & Temperature & Cell sheet engineering & [93] \\
\hline
\end{tabular}

These biomaterials have been used in several applications, including TE and drug release, and have been characterized according to their properties, biocompatibility in particular [24]. Hence, this temperature-driven mechanism is a candidate for a good case scenario in $4 \mathrm{D}$ (bio-)printing, as shape transformation can be achieved by changing temperature within a reasonable range and possibly encapsulating cells into the thermosensitive hydrogel [16]. Also, biological origin polymers can be entitled with a thermoresponsive behavior, such as methyl cellulose hydrogel, which is proposed as a substrate for cell sheet engineering [93].

\subsection{Electrically and Mechanoelectrically Responsive Materials}

Most smart electrically responsive materials usually depend on their electrically conductive characteristics. Upon an electric field, a hydrogel will swell or contract depending on its charge. Electric field responsiveness is, in fact, a combination of several electrical interactions occurring in hydrogels, including Coulombic, electrophoretic, electroosmotic, and piezoelectric phenomena. Electrical properties of these types of hydrogels can be regulated by the intensity or direction of the externally applied electric field. This feature provides new applications for biomimetic systems, since materials can change their size and/or shape in response to electrical stimulation [16]. Electrical and electrochemical stimuli have been widely used in research and applications due to their advantages of precise control through the magnitude of the current, the duration of an electric pulse or the pulse interval [65]. As an external stimulus, an electric field presents some advantages such as: (i) the availability of equipment that allows a precise control considering the magnitude of the current; (ii) the duration of the electric pulses, and (iii) the intervals during pulses [41]. In Table 3, the reported trials using electricity as a predefined stimulus are collected. 
Table 3. Overview of the experiments on $4 \mathrm{D}$ (bio-)printing and other manufacturing approaches using electricity as a predefined stimulus.

\begin{tabular}{cccc}
\hline Material(s) & Mechanism(s) & Application(s) & Ref. \\
\hline Polythiophene (PT) & Electricity & $\begin{array}{c}\text { Drug delivery, biosensing, } \\
\text { implant devices }\end{array}$ & {$[94,95]$} \\
Sulfonated-polystyrene (PSS) & Electricity & $\begin{array}{c}\text { Active ingredients in } \\
\text { marketed vaginal } \\
\text { contraceptive }\end{array}$ & [96] \\
\hline $\begin{array}{c}\text { Poly(2-(acrylamide)-2-methylpropanesulfonic } \\
\text { acid) (PAMPS) }\end{array}$ & Electricity & $\begin{array}{c}\text { Actuators or artificial } \\
\text { muscles }\end{array}$ & [97] \\
\hline $\begin{array}{c}\text { Poly(2-hydroxyethyl methacrylate) } \\
\text { (PHEMA) }\end{array}$ & Electricity & [98] \\
\hline $\begin{array}{c}\text { Poly(L-lactic } \\
\text { acid)/Poly(3,4-ethylenedioxythiophene) } \\
\text { (PLLA/PEDOT) }\end{array}$ & Electricity & $\begin{array}{c}\text { Electrically conductive 3D } \\
\text { scaffold for tissue } \\
\text { engineering }\end{array}$ & [99] \\
\hline $\begin{array}{c}\text { Poly(3,4-ethylenedioxythiophene) } \\
\text { polystyrene sulfonate (PEDOT:PSS) }\end{array}$ & Electricity & $\begin{array}{c}\text { Smart Micro } \\
\text { Electro-Mechanical Systems } \\
\text { (MEMS) interface } \\
\text { applications, neural tissue } \\
\text { engineering }\end{array}$ & {$[100-102]$} \\
\hline
\end{tabular}

Electrically responsive hydrogels are prepared from polyelectrolytes (i.e., polymers that contain high concentrations of ionizable groups along the chain and, therefore, are sensitive to electrical stimuli) and electroresponsive polymers can be used to prepare materials that swell, contract or bend in response to an electric field.

The polyelectrolyte hydrogels are electroresponsive polymers and can deform under an electric field, due to swelling or contract because the charged ions are directed to the anode or cathode of the gel [41]. It should be considered that also electrically unresponsive hydrogels may show an electric responsiveness in presence of dielectric liquids or in combination with electrically responsive nanoparticles $[43,103]$. Electrically responsive polymers are also called conducting polymers, such as polythiophene (PT) [94,95] and sulfonated-polystyrene (PSS) [96], which may undergo swelling, shrinkage, or flexion in response to an electrical stimulus.

The most employed natural polymers used to prepare electroresponsive materials are chitosan, chondroitin sulfate, hyaluronic acid, and alginate [14,104]. Major synthetic polymers have been based on vinyl alcohol, allylamine, acrylonitrile, 2-acrylamido-2-methylpropane sulfonic acid (PAMPS), aniline, poly(2-hydroxyethyl methacrylate) (PHEMA), methacrylic acid, acrylic acid, and vinyl sulfonic acids [41]. Specifically, PAMPS [97], PHEMA [98], and a few others represent best known examples of these hydrogels. Different effects concur with electrical stimulation: (i) increases in the osmotic pressure of the polymer due to an influx of counterions and solvent molecules, (ii) control of the charge/adsorption of polyelectrolyte on the charge opposite to porous materials, and (iii) formation and swelling of active redox polyelectrolyte multilayers [65].

Although PT has shown no evidence of cytotoxicity, few studies have been carried out for understanding potential suitability in the biomedical field [94,95]. Likewise, PSS has exhibited a low or even no degree of cytotoxicity to primary human cervical cells even at high concentrations, and it is a promising candidate for biomedicine applications [96]. PLLA/poly(3,4-ethylenedioxythiophene) (PLLA/PEDOT) has been used for electrically conductive 3D scaffold for TE application [99]. Some reports used poly(3,4-ethylenedioxythiophene):polystyrene sulfonate (PEDOT:PSS) as an electrical stimulus polymer for smart micro-electromechanical systems (MEMS) interface or neural TE (Figure 5) [100-102]. For example, an immunofluorescence study was carried out using specific antibodies against Tuj1. Neural stem cells on crosslinked PEDOT:PSS substrates with and without electrical stimulation, differentiated into neurons and into astrocytes confirmed by Tuj1 and GFAP 
immunoreactivity, respectively (Figure 5). Results show that electrical stimulation significantly increases the percentage of Tuj1-positive cells [101].

(a)

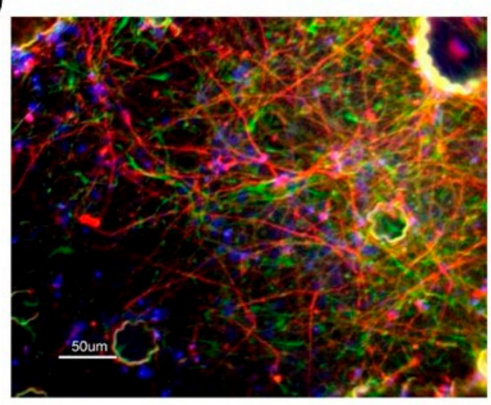

(b)

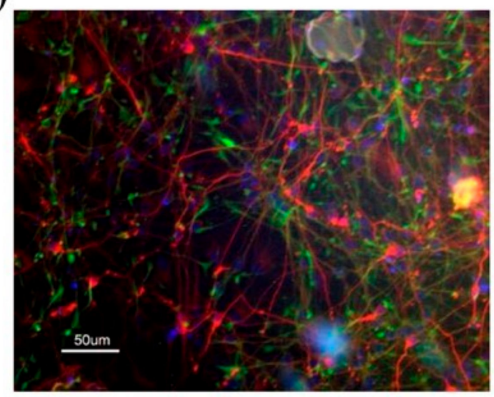

(c)

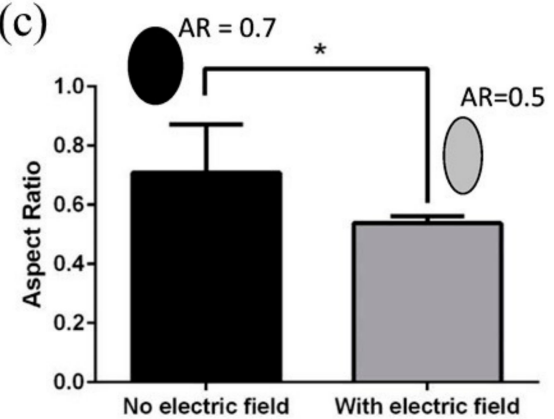

(d)

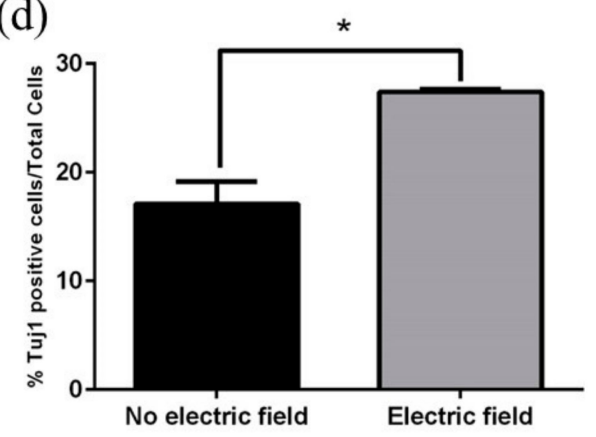

Figure 5. Immunofluorescence images of anti-Tuj1 (red) and anti-GFAP (green) followed by DAPI (blue) staining for the nuclei of the fetal NSCs on crosslinked PEDOT:PSS. NSCs differentiation occurred on crosslinked PEDOT:PSS substrates without (a) and with (b) electric stimulation. (c) Quantification of aspect ratio of neurons. More than 30 cells were analyzed. (d) Quantification of percentage Tuj1 positive. ${ }^{*} p<0.05$. Reprinted with permission [101] @ 2020 Elsevier.

\subsection{Magnetically Responsive Materials}

Polymers that respond to the presence or absence of magnetic fields may exist as free strands in solution, or may be framed on surfaces or be crosslinked inside polymer networks. Typically, inorganic magnetic particles called "nanos" are covalently immobilized on 3D lattices, causing the materials to have a change in shape and size, the latter occurring instantaneously in the presence of a nonuniform magnetic field, which makes the process reversible. In this case, the stimulation imparted to the polymers results in a magnetic susceptibility, leading to a great interest in such materials for their use as soft biomimetic actuators, sensors, cancer therapy agents, artificial muscles, separation media, membranes, and drug delivery systems $[41,105,106]$.

During the printing process, a magnetic field is applied to control the orientation of printed anisotropic particles containing rigid magnetized plates. The composition of biomaterials can be controlled by using only a two-component unit or more materials to form a single geometry, thereby adding an extra dimension to the available design space, and ultimately allowing the fabrication of functional constructs that can mimic the intricate biological constructs in nature [24].

Magnetic hydrogels are a combination of hydrogel systems with magnetic nanoparticles (MNP). MNPs, such as cobalt ferrite $\left(\mathrm{CoFe}_{2} \mathrm{O}_{4}\right)$, iron platinum (FePt), iron (III) oxide $\left(\mathrm{Fe}_{2} \mathrm{O}_{3}\right)$, and iron (II, III) oxide $\left(\mathrm{Fe}_{3} \mathrm{O}_{4}\right)$, respond to magnetic stimuli, ultimately leading to hydrogel deformations $[29,40,107,108]$. Some reports describe a combination of magnetic $\mathrm{Fe}_{3} \mathrm{O}_{4}$ particles with different polymers as semiconductors or active scaffolds used for on-demand drug and cell delivery [105,106,109-112]. In another attempt, iron nanoparticles/[11-(2-bromo-2-methyl)-propionyloxy]undecyltrichlorosilane (Fenp-PS gel) was used for cancer therapy [113]. The toxicity of cobalt ferrite is dose dependent; i.e., 
low quantities induce no interference with cell viability, whereas high quantities lead to a significant decrease of the viability [96].

There are several studies that indicate the level of toxicity of FePt but it highly depends on the surface coating, the concentration, the Fe precursor, and the cell lines used. In some cases, it has been shown that the level of toxicity is low with no relevant effect on cell viability [96]. To detect the toxicity of iron oxide, several studies have been carried out, which, however, have brought discordant results. They indicate that the size of the particle and the surface coatings are crucial for the effects induced by iron oxide since they determine the intensity of the effects and the potential mechanisms of cellular toxicity [114].

Magnetism is widely used in the biomedical field, for instance, to control the release of drugs [24], as ferrogels respond to magnetic stimuli. These ferrogels lie in the nanometer scale, which may limit the transport of large molecules and cells through the gels. To create greater cell adhesion and to produce the release of large molecules, magnetic scaffolds have been produced with larger pores connected three-dimensionally and coupled with magnetic nanoparticles and cell-binding peptides (Figure 6) [112]. 4D (bio-)printed materials using magnetism as a stimulus are reported in Table 4.

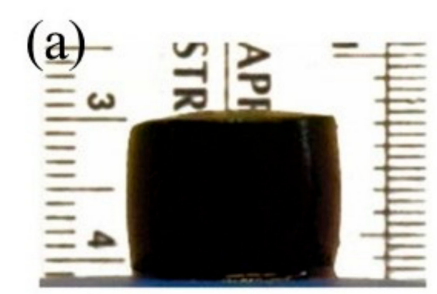

(b)

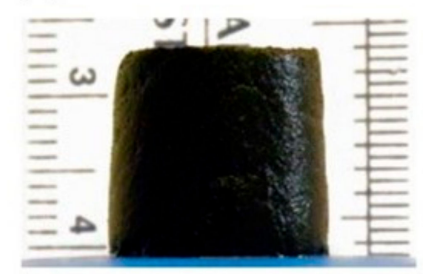

(c)

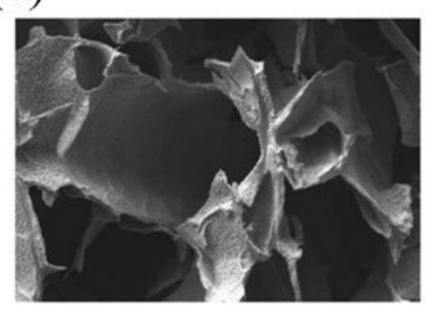

Undeformed

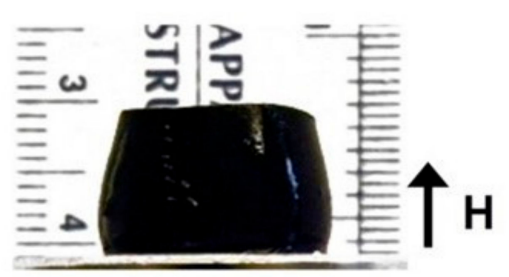

Field on

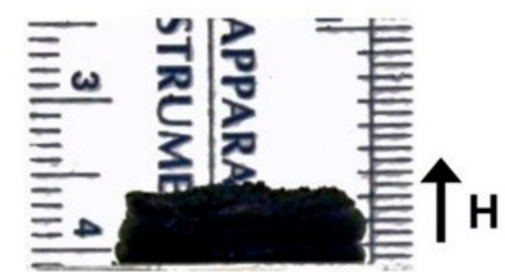

Field on

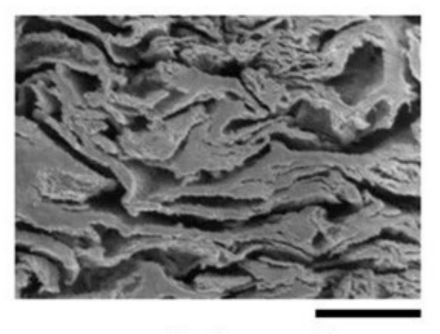

Deformed

Figure 6. (a) A cylinder of a nanoporous ferrogel reduced its height $\sim 5 \%$ when subjected to a vertical magnetic-field gradient of $\sim 38 \mathrm{~A} / \mathrm{m} 2$. (b) The corresponding macroporous ferrogel deformed $\sim 70 \%$ under the same magnetic field. (c) SEM images of a freeze-dried macroporous ferrogel in the undeformed and deformed states. (Scale bar: $500 \mu \mathrm{m}$ ). Reprinted with permission [112] (C) 2020 National Academy of Sciences.3.5. Photoresponsive Materials. 
Table 4. Overview of the experiments on $4 \mathrm{D}$ (bio-)printing and other manufacturing approaches using magnetism as a predefined stimulus.

\begin{tabular}{cccc}
\hline Material(s) & Mechanism(s) & Application(s) & Ref. \\
\hline Cobalt ferrite $\left(\mathrm{CoFe}_{2} \mathrm{O}_{4}\right)$ & Magnetism & Controlled drug release & {$[29,108,115]$} \\
\hline Ferromagnetic cobalt nanoparticles & Magnetism & & {$[107]$} \\
\hline Iron platinum $(\mathrm{FePt})$ & Magnetism & & {$[29,115]$} \\
\hline Iron (III) oxide $\left(\mathrm{Fe}_{2} \mathrm{O}_{3}\right)$ & Magnetism & Drug delivery application & {$[29,115]$} \\
\hline Iron (II, III) oxide $\left(\mathrm{Fe}_{3} \mathrm{O}_{4}\right)$ & Magnetism & & {$[29,115]$} \\
\hline CoPt & Magnetism & Drug delivery application & {$[115]$} \\
\hline $\begin{array}{c}\text { Poly(acrylamide), alginate } \\
\left.\text { Pola } \mathrm{O}_{4}\right) \text { with PNIPAM, PVA, }\end{array}$ & Magnetism & $\begin{array}{c}\text { Semiconductor, active } \\
\text { scaffolds for on-demand } \\
\text { drug and cell delivery }\end{array}$ & {$[105,106,109,110,112]$} \\
\hline $\begin{array}{c}\text { Iron nanoparticles/[11-(2-bromo- } \\
\text { 2-methyl)-propionyloxy] } \\
\text { undecyltrichlorosilane (Fenp-PS gel) }\end{array}$ & Magnetism & $\begin{array}{c}\text { Cancer therapy, sensors, } \\
\text { switches, various } \\
\text { separations, membranes, } \\
\text { and drug delivery systems }\end{array}$ & {$[113]$} \\
\hline
\end{tabular}

Photosensitive polymers are macromolecules that alter their structural properties upon irradiation with light at a given wavelength. These changes occur when light radiates specific functional groups along the polymer chain [41]. The strong light attenuation in biological tissues can present a challenge to this strategy, causing nonuniform illumination and transformation. On the other hand, near-infrared (NIR) light, representing a biosafe wavelength range, can be used to improve light penetration in bioprinted photosensitive tissue constructs [24]. Photocatalyzed reactions have shown a strong correlation to the light irradiance (i.e., radiant flux by surface area), thus becoming attractive tools for hydrogel manipulation [116].

The light can be applied instantaneously directly on the surface of the polymer or in distant locations using optical fibers, and under specific conditions with high precision, making photosensitive polymers quite advantageous for various applications. The wavelength of the laser must be tuned, near the infrared spectrum, in the so-called biologically "friendly" window, because it is less harmful than UV and penetrates deeper into tissues than light in the visible spectrum. In this case, the light is absorbed as little as possible by the cells and tissues and as much as possible by the polymers, thus enabling controlled therapy and diagnostics [117,118]. Most photoresponsive polymers contain light sensitive chromophores, such as azobenzene groups, spiropyran groups, or nitrobenzyl groups. A variety of photovoltaic polymers containing azobenzene [119-122], spiropyran [122,123], nitrobenzyl [122,124] have been reported, such as poly(acrylic acid) (PAA) [125], poly(N-(2-hydroxypropyl) methacrylamide) (PHPMAm) [126,127], and PNIPAAm [74]. Azobenzene is one of the most well-studied photochromic molecules because of its reversible photoisomerization depending on the wavelength of light.

Photosensitive polymers contain photoactive groups that may undergo reversible structural changes when they come into contact with UV-Vis light. These functional fragments alter size and shape, or form ionic species after irradiation (Figure 7a) $[65,128,129]$. Recent efforts have demonstrated the possibility of controlling 2D and 3D hydrogel fabrication along a time and space scale (Figure 7b) [130].

According to recent studies with PAA and human liver cancer cells, they demonstrated to have a desired cytotoxic activity [131]. The polymer PHPMAm is hydrophilic, biocompatible, and is not immunogenic [132]. Tests performed on different cell types with PNIPAAm revealed that the cell sensitivity varies according to cell type, being advisable to always perform toxicity tests; the purity of the polymer also influences the results [74]. An important feature of light sensitive polymers is that irradiation as a stimulus is a relatively simple and noninvasive mechanism to induce a responsive behavior $[41,89,133]$. Cell-containing polymers can be readily crosslinked with exposure to UV light. During the curing process, photoinitiators generate free radicals to initiate the polymerization process. 
Exposure time, light intensity, and adequate photoinitiator should be examined and assessed to ensure that no damage will affect the cells [29].

Possible applications of photoresponsive polymers include reversible optical storage, polymer viscosity control, transduction and photomechanical performance, exchange of protein bioactivity, TE, and drug delivery $[41,133,134]$. For example, poly(1-pyrenylmethyl methacrylate) (PEO-PPyMA), poly(2-nitrobenzylmethyl methacrylate) PEO-b-PNBMA, and PEO-b-P(MA-DEACM) have been used as light-responsive polymers to produce micelles in anticancer therapy (Figure 7c) [135-137]. A list of materials using light as a $4 \mathrm{D}$ stimulus is summarized in Table 5.

Table 5. Overview of the experiments on $4 \mathrm{D}$ (bio-)printing and other manufacturing approaches using light as a predefined stimulus.

\begin{tabular}{|c|c|c|c|}
\hline Material(s) & Mechanism(s) & Application(s) & Ref. \\
\hline $\begin{array}{l}\text { Polymers containing } \\
\text { Azobenzene groups }\end{array}$ & $\begin{array}{l}\text { Light (ultraviolet (UV) } \\
\text { light) }\end{array}$ & Swimming soft robot & [119-121] \\
\hline $\begin{array}{l}\text { Polymers containing } \\
\text { Spiropyran groups }\end{array}$ & Light & & [123] \\
\hline $\begin{array}{l}\text { Polymers containing } \\
\text { Nitrobenzyl groups }\end{array}$ & Light & & [124] \\
\hline $\begin{array}{c}\text { Poly (acrylic acid) (PAA) } \\
\text { containing Azobenzene groups }\end{array}$ & Light & & [125] \\
\hline $\begin{array}{c}\text { Poly (N-(2-hydroxypropyl) } \\
\text { methacrylamide) (PHPMAm) } \\
\text { containing Azobenzene groups }\end{array}$ & Light & $\begin{array}{l}\text { Polymeric micelles in } \\
\text { anticancer therapy, scaffold } \\
\text { for tissue engineering }\end{array}$ & {$[126,127]$} \\
\hline PNIPAAm & Light & & [74] \\
\hline $\begin{array}{c}\text { PEO-PPyMA } \\
\text { (poly(1-pyrenylmethyl } \\
\text { methacrylate) }\end{array}$ & Light & $\begin{array}{l}\text { Micelles in } \\
\text { anticancer therapy }\end{array}$ & {$[136,137]$} \\
\hline $\begin{array}{c}\text { PEO-b-PNBMA } \\
\text { (poly(2-nitrobenzylmethyl } \\
\text { methacrylate) })\end{array}$ & Light (UV/NIR) & $\begin{array}{l}\text { Micelles in } \\
\text { anticancer therapy }\end{array}$ & [137] \\
\hline PEO-b-P(MA-DEACM) & Light (UV/NIR) & $\begin{array}{c}\text { Micelles in } \\
\text { anticancer therapy }\end{array}$ & [135] \\
\hline
\end{tabular}


(a)

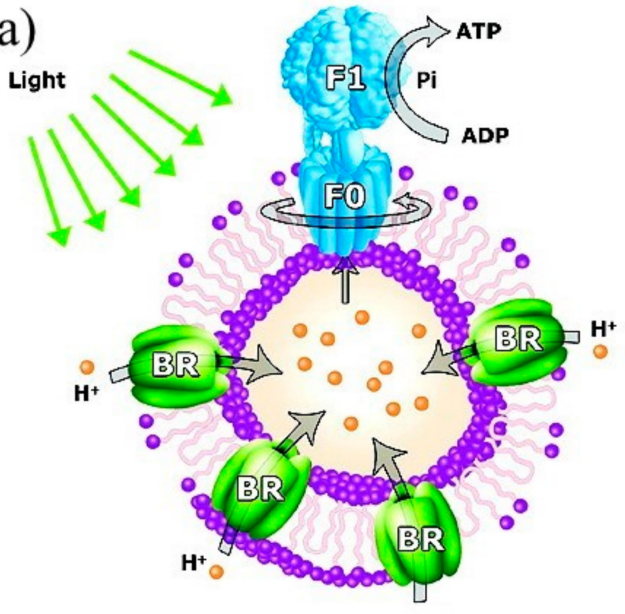

(c)
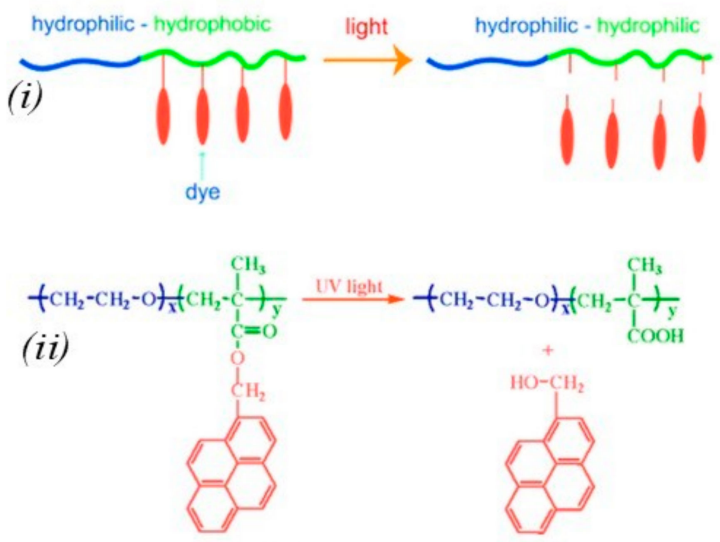
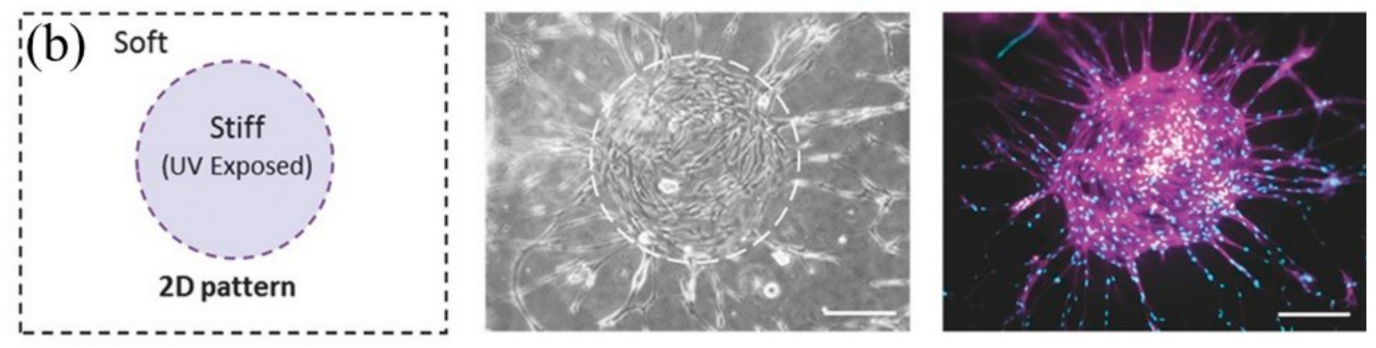

Figure 7. Photoresponsive materials: (a) Schematic representation of proteopolymersomes reconstituted with both BR and F0F1-ATP synthase. ATP synthase uses an electrochemical proton gradient generated by BR to synthesize ATP from ADP and inorganic phosphate. Reprinted with permission [138] (C) 2020 American Chemical Society. (b) 2D pattern with circular exposed spot: cells' preferential adhesion, spreading, and proliferation are visible on the UV-exposed area after $4 \mathrm{~d}$ of culture. Reprinted with permission [130] (C) 2020 John Wiley and Sons. (c) Schematic illustration of light effect: (i) detachment of dye pendant groups resulting in the hydrophobic-to-hydrophilic switch and (ii) chemical structure of the pyrene-containing amphiphilic diblock copolymer and its photosolvolysis under UV light irradiation. Reprinted with permission [136] (c) 2020 American Chemical Society.

\section{5. $p H$-Responsive Materials}

Body $\mathrm{pH}$ can greatly vary as a consequence of both normal (e.g., in the gastrointestinal, vaginal) and diseased conditions (e.g., bone fracture, inflammation, tumors, some cardiovascular defects, infected wounds). The most remarkable example occurs in the gastrointestinal tract, where $\mathrm{pH}$ increases from 1 to 8 , passing from the stomach to the intestine. Therefore, responsive biomaterials able to properly interact with such $\mathrm{pH}$ variations can be highly useful in drug delivery [139-150]. Specifically, $\mathrm{pH}$-responsive hydrogels react to $\mathrm{pH}$ changes in the microenvironment by volume expansion/contraction, namely via swelling/deswelling. This phenomenon is caused by the ionization of pendant groups, such as amine and carboxylic acid groups. Indeed, the presence of ions affects the osmotic pressure, which in anionic and cationic hydrogels causes swelling at $\mathrm{pH}>\mathrm{pKa}$ and $\mathrm{pH}<\mathrm{pKa}$, respectively (Figure 8). 


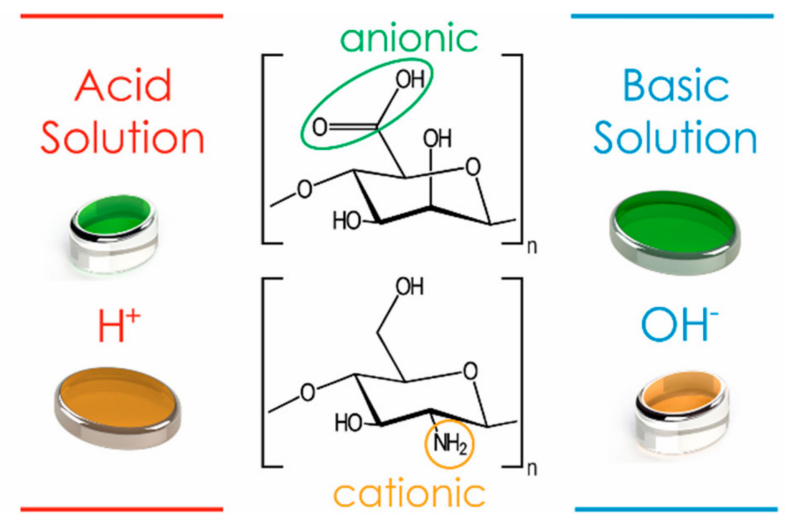

Figure 8. Schematics showing the swelling/deswelling behavior of $\mathrm{pH}$-responsive hydrogels in acid and basic solutions, depending on their ionic nature, anionic or cationic. (Original figure from the authors).

Both synthetic and natural polymer hydrogels can show $\mathrm{pH}$-responsiveness. Synthetic polymers include PAA [140,143,146], poly(methacrylic acid) (PMAA) [143], poly(acrylamide/maleic acid) [P(AAm/MA)] [150], poly(diethylaminoethyl methacrylate) (PDEAEMA) [143], poly(dimethylaminoethyl methacrylate) (PDMAEMA) [143,149], PHEMA [142], some copolymers include poly(2-(diethylamino)ethyl methacrylate-co-2-(dimethylamino)ethyl methacrylate)-b-poly(2(dimethylamino)ethyl methacrylate) P(DEAEMA-co-DMAEMA)-b-PDMAEMA [151] and poly (DMAPMA-co-HEMA) [145].

Among natural macromolecules, some proteins (e.g., gelatin, albumin) [152] as well as polysaccharides (e.g., alginate, chitosan) $[148,153,154]$ can give rise to $\mathrm{pH}$-responsive hydrogels (Figure 2). Poly(N-isopropyl acrylamide-co-butyl methacrylate-co-acrylic acid) [155] and star-branched poly( $\varepsilon$-caprolactone)-b-poly(2-(dimethylamino)ethyl methacrylate) (HPs-star-PCL-bPDMAEMA) [156] have been used as $\mathrm{pH}$ and temperature sensitive polymers for controlled drug delivery application. Several of these polymers have been used for $4 \mathrm{D}$ (bio-)printing by virtue of $\mathrm{pH}$ as a predefined stimulus to be exploited (Table 6).

Table 6. Overview of the experiments on $4 \mathrm{D}$ (bio-)printing and other manufacturing approaches using $\mathrm{pH}$ as a predefined stimulus.

\begin{tabular}{|c|c|c|c|}
\hline Material(s) & Mechanism(s) & Application(s) & Ref. \\
\hline Poly(acrylic acid) (PAA) & $\mathrm{pH}$ & $\begin{array}{l}\text { Peroral-controlled drug } \\
\text { delivery, taste-masking of } \\
\text { bitter drugs, and } \\
\text { intravascular drug release } \\
\text { during elevated blood pH in } \\
\text { certain cardiovascular } \\
\text { defects }\end{array}$ & [143] \\
\hline Poly(acrylic acid) (PAA):PEO & $\mathrm{pH}$ & Drug delivery & [140] \\
\hline $\begin{array}{l}\text { Based on gelatin (G) and acrylic acid } \\
\text { (AAc) }\end{array}$ & $\mathrm{pH}$ & $\begin{array}{l}\text { Colon-specific oral drug } \\
\text { delivery }\end{array}$ & [146] \\
\hline Poly(methacrylic acid) (PMAA) & $\mathrm{pH}$ & & [143] \\
\hline $\begin{array}{l}\text { Poly(acrylamide/maleic acid) } \\
\text { (P(AAm/MA)) }\end{array}$ & $\mathrm{pH}$ & Drug delivery & [150] \\
\hline $\begin{array}{l}\text { Poly(diethylaminoethyl methacrylate) } \\
\text { (PDEAEMA) }\end{array}$ & $\mathrm{pH}$ & & [143] \\
\hline $\begin{array}{l}\text { Poly(dimethylaminoethyl methacrylate) } \\
\text { (PDMAEMA) }\end{array}$ & $\mathrm{pH}$ & Drug delivery, DNA transfer & {$[143,149]$} \\
\hline
\end{tabular}


Table 6. Cont.

\begin{tabular}{|c|c|c|c|}
\hline Material(s) & Mechanism(s) & Application(s) & Ref. \\
\hline Poly (DMAPMA-co-HEMA) & $\mathrm{pH}$ & Anticancer drug delivery & [144] \\
\hline Chitosan-PEO & $\mathrm{pH}$ & Drug delivery & [145] \\
\hline Chitosan and polyacrylamide (PAAm) & $\mathrm{pH}$ & $\begin{array}{l}\text { Biomedical field or in } \\
\text { agriculture }\end{array}$ & [141] \\
\hline Gelatin-PEO & $\mathrm{pH}$ & Drug delivery & [139] \\
\hline $\begin{array}{l}\text { Poly(2-hydroxyethyl methacrylate) } \\
\text { (PHEMA) }\end{array}$ & $\mathrm{pH}$ & Drug delivery & [142] \\
\hline $\begin{array}{l}\mathrm{N} \text {-vinyl pyrrolidone, polyethylene } \\
\text { glycol diacrylate, chitosan }\end{array}$ & $\mathrm{pH}$ & Drug delivery & [148] \\
\hline Sulfonamide/polyethyleneimine (PEI) & $\mathrm{pH}$ & Tumor specific gene delivery & [147] \\
\hline $\begin{array}{l}\text { Poly(2-(diethylamino)ethyl } \\
\text { methacrylate-co-2-(dimethylamino)ethyl } \\
\text { methacrylate)-b-poly(2-(dimethylamino) } \\
\text { ethyl methacrylate), P(DEAEMA-co- } \\
\text { DMAEMA)-b-PDMAEMA }\end{array}$ & $\mathrm{pH}$ & & [151] \\
\hline Albumin & $\mathrm{pH}$ & Theragnostic agent & [152] \\
\hline Alginate/Chitosan & $\mathrm{pH}$ & Drug delivery & [154] \\
\hline Alginate & $\mathrm{pH}$ & Drug delivery & [153] \\
\hline $\begin{array}{l}\text { Poly(N-isopropyl acrylamide-co-butyl } \\
\text { methacrylate-co-acrylic acid) }\end{array}$ & $\mathrm{pH}$ and temperature & Drug delivery & [155] \\
\hline $\begin{array}{c}\text { Star-shaped poly(e-caprolactone)- } \\
\text { b-poly(2-(dimethylamino)ethyl } \\
\text { methacrylate) } \\
\text { (HPs-Star-PCL-b-PDMAEMA) }\end{array}$ & $\mathrm{pH}$ and temperature & Controlled drug delivery & [156] \\
\hline
\end{tabular}

\subsection{Other Stimuli-Responsive Materials}

In addition to the previous cited classes, we report in this section other stimuli-responsive materials, triggered by mechanical [157], chemical [41,65,158] and glucose-based stimuli [159,160], which are summarized along with their application in Table 7.

Mechanically or shear-responsive hydrogels respond to mechanical perturbations in the environment. They can modulate their intrinsic viscoelastic properties depending on the applied shear stress, thus showing either shear-thinning or shear-thickening behaviors. Indeed, the viscosity decreases in shear-thinning whereas it increases in shear-thickening hydrogel, as a function of an external force [161]. Shear-thinning is observed in self-assembled polymeric systems and is usually reversible. It can be very convenient to produce injectable biomaterials [162]. Conversely, shear-thickening deals with colloidal suspensions and is exhibited only in some shear ranges. One example is elastin-like cysteine-containing hydrogel [157]. Shear-thickening or dilatant fluids are difficult to use as printing inks, in particular in fast-running processes due to high shear stress [163].

Polymers that can transform mechanical into electrical energy and vice versa are piezoelectric, and suggest promising applications in biomechanics, artificial muscle performance, sensors, energy transduction, sound deadening, chemical separations, and controlled drug delivery (Table 7) [164]. Piezoelectricity is widely diffused in nature and it is believed that bioelectric stimuli deriving from mechanical forces may trigger fundamental biological functions; in fact, piezoelectricity has been observed in many biopolymers, like collagen, elastin, and chitin [165].

Synthetic piezoelectric polymers mainly belong to the poly(vinylidene fluoride) (PVDF) and its copolymers, such as $\mathrm{P}(\mathrm{VDF}-$ trifluoro ethylene) $[\mathrm{P}(\mathrm{VDF}-\mathrm{TrFE})]$. By also incorporating piezoelectric ceramic nanoparticles, like $\mathrm{BaTiO}_{3}, \mathrm{LiNbO}_{3}$, and $\mathrm{ZnO}$, PVDF-based polymers enhance their piezoelectric 
properties, useful in inner ear devices and lung tissue engineering, together with antibacterial and immunomodulatory activity [166-168]. Moreover, PVDF-based devices can be applied as energy harvesters in several applications considering piezo-triboelectric effects $[169,170]$.

Different piezoelectric nanoparticle-polymer composite materials with the ability of conversion compressive/tensile stresses to an electric charge, or vice versa, have also been used in 3D printing to the creation of a wide variety of smart structures [171-176].

The one-step 3D printing of piezoelectric materials opens up a new demographic of sensor designs, and also 3D piezoelectric scaffolds could be used as electroactive scaffolds in TE, providing a biomimetic environment for cell culture. By chemically modifying the surface of the $\mathrm{BaTiO}_{3}$ nanoparticles with linker molecules that crosslink with the polymer matrix under light exposure, Kim et al. increased the mechanical-to-electrical conversion process of nanocomposites, which can be used for different applications such as implantable medical devices [176].

Bodkhe et al. investigated the effect of addition of barium titanate $\left(\mathrm{BaTiO}_{3}\right)$ nanoparticles in nucleating piezoelectric $\beta$-polymorph in 3D printable PVDF and fabrication of the layer-by-layer and self-supporting piezoelectric structures on a micro- to millimeter scale [171]. Thermo-mechanically responsive materials, such as glassy shape memory polymers (GSMPs) have also been used for some specific applications such as active origami $[177,178]$.

Ge et al. [178] created a printed active composite (PAC) consisting of GSMPs fibers with tailored thermomechanical behavior in an elastomeric matrix to be used as hinges to connect inactive plates of stiff plastic to enable a self-folding box. The multiple film layers have been printed to create the $3 \mathrm{D}$ laminate. PAC displays the shape memory effect in the range of $\mathrm{T}_{\mathrm{L}}=15^{\circ} \mathrm{C}$ to $\mathrm{T}_{\mathrm{H}}=60^{\circ} \mathrm{C}$. Thus during a temperature cycle between $\mathrm{T}_{\mathrm{L}}$ and $\mathrm{T}_{\mathrm{H}}$, the matrix with a glass transition temperature of $\mathrm{Tg}=$ $5{ }^{\circ} \mathrm{C}$ is always rubbery, while the fibers undergo a glass temperature $(\mathrm{Tg})$ that lets them be used as the switchable segment in the composite.

Chemically responsive hydrogels show swelling or degradation in response to a defined target molecule. The primary example is glucose-responsive hydrogels that exploit the competitive reaction and best affinity for glucose of concanavalin A [158]. Glucose-responsive polymers have received considerable attention because of their application. One of the applications is the huge potential in the self-regulated modes of insulin delivery where a smart delivery system is used, in which insulin delivery is automatically triggered by a rise in blood glucose levels $[41,65]$.

Table 7. Overview of the experiments on 4D (bio-)printing and other manufacturing approaches using chemical and mechanical-based forces as a predefined stimuli.

\begin{tabular}{cccc}
\hline Material(s) & Mechanism(s) & Application(s) & Ref. \\
\hline Glucose-responsive hydrogels & Chemistry & Diabetes monitoring & {$[41,65,158]$} \\
\hline Glucose oxidase & Chemistry & Drug delivery & {$[159]$} \\
\hline Glucose oxidase & Chemistry & $\begin{array}{c}\text { Controlled release of } \\
\text { insulin }\end{array}$ & {$[160]$} \\
\hline $\begin{array}{c}\text { Cysteine-containing hydrogel } \\
\text { Barium titanate (BaTiO3, BTO) } \\
\text { nanoparticles }\end{array}$ & Mechanical force & Injectable biomaterial & {$[157]$} \\
\hline $\begin{array}{c}\text { into a polyethylene glycol diacrylate } \\
\text { (PEGDA) matrix }\end{array}$ & $\begin{array}{c}\text { Stress (piezoelectric) } \\
\text { Implantable medical } \\
\text { devices }\end{array}$ & [176] \\
\hline $\begin{array}{c}\text { BaTiO3 (BTO) filler in a poly(vinylidene) } \\
\text { fluoride (PVDF) }\end{array}$ & $\begin{array}{c}\text { Mechanical force } \\
\text { (piezoelectric) }\end{array}$ & Pressure sensor & {$[179]$} \\
\hline $\begin{array}{c}\text { Ultraviolet-curable resins (acrylate ester } \\
\text { for Resin 1, and methacrylated } \\
\text { monomers/oligomers for Resin 2) }\end{array}$ & $\begin{array}{c}\text { Mechanical force } \\
\text { (piezoelectric) }\end{array}$ & N/A & {$[172]$} \\
\hline
\end{tabular}


Table 7. Cont.

\begin{tabular}{cccc}
\hline Material(s) & Mechanism(s) & Application(s) & Ref. \\
\hline $\begin{array}{c}\text { BaTiO } 3 \text { powder and photocurable } \\
\text { resin SI500 }\end{array}$ & $\begin{array}{c}\text { Mechanical force } \\
\text { (piezoelectric) }\end{array}$ & $\begin{array}{c}\text { Energy focusing and } \\
\text { ultrasonic sensing }\end{array}$ & {$[173]$} \\
\hline $\begin{array}{c}\mathrm{BaTiO}_{3} \text { nanoparticles in nucleating } \\
\text { piezoelectric } \beta \text {-polymorph in 3D } \\
\text { printable polyvinylidene fluoride } \\
\text { (PVDF) }\end{array}$ & $\begin{array}{c}\text { Mechanical force } \\
\text { (piezoelectric) }\end{array}$ & Integrable sensors & {$[171]$} \\
\hline $\begin{array}{c}\text { Multiwall carbon nanotubes } \\
\text { (MWCNTs)/PVDF/BaTiO }\end{array}$ nanoparticles & $\begin{array}{c}\text { Mechanical force } \\
\text { (piezoelectric) }\end{array}$ & Sensor & {$[174]$} \\
\hline Shape memory polymer & Thermomechanical & Active origami & {$[177]$} \\
\hline Glassy shape memory polymer & Thermomechanical & Active origami & {$[178]$} \\
\hline
\end{tabular}

\section{4D (Bio-)printing: Cutting Edge Applications and Future Perspectives}

3D printing has become a growing industry. New materials, printing methods, software, and machines are constantly being developed and improved, making 4D printing a more realistic and affordable option. The main difference between $3 \mathrm{D}$ and $4 \mathrm{D}$ printing is the possibility to trigger a planned time-scale modification of specific feature (e.g., shape, size) in the printed constructs, thus opening the opportunity of programmed response to changing environments and needs [180].

The concept of $4 \mathrm{D}$ printing is relatively young, becoming very fashionable for numerous engineering applications, including structural, aerospace, and biomedical, namely, in those applications where the microenvironment changes play a fundamental role in the material function [181-186]. 4D (bio-)printing, despite a full consensus on the exact definition, has the potential to physically replicate the path of developmental biology and bring organ printing a step closer to reality, thus combining life sciences with engineering in a dynamic fashion. This technology has emerged as a useful tool for biomedical applications because of its innate advantages, including (i) complex 3D structures based on materials that respond to environmental stimuli and can reshape or alter their function, and (ii) postmaturation of cell populations printed on scaffolds with programmable architectures enable the generation of tissue constructions with functionalities similar to native tissues [24].

Recent advances in understanding the structure of blood vessels and the evolution of 4D (bio-)printing can improve vessel constructions and various other constructs that mimic native tissue. In the case of blood vessels, these are the ones that maintain cellular function through the supply of nutrients and oxygen and waste removal. 4D printed constructs for blood vessels are manufactured as layer-by-layer solids, where the cells are mixed in the hydrogels and the cylindrical structures obtained resemble the blood vessels [187]. These cellularized hydrogels are subsequently activated by maturation factors, and the cells rapidly mature, resulting in vascularization. Polymers that are sensitive to different stimuli also have applicability in regenerative medicine. They can be classified into polymers with smart surfaces and polymers subjected to sol-gel transition for injectable implants. The former can be used as scaffolds with excellent ability to control the properties of surfaces, enabling the adsorption or desorption of molecules and cells. Depending on the application, polymers that respond to stimuli may enable the production of smart scaffolds for TE via 3D printing also aided by other technologies [65]. Interesting examples of regenerative applications include 4D biofabrication of fibrous artificial nerve graft [188], and skeletal muscle microtissues [189].

However, the printability of these polymers must be assessed. It is fundamental to precisely control deposition of hydrogels during printing. Therefore, the printing parameters, such as air pressure, feed rate, and printing distance need to be mastered [190]. Printability of hydrogels can be assessed by depositing one dimensional (1D), 2D, and up to 3D structures in order to understand the real versus designed outline accuracy. Piezoelectric materials have been successfully 3D printed with methods that also integrate poling treatments [191]. 3D printed PVDF structures have indeed 
boosted the emerging field of piezoelectronics, which has remarkable applications in the biomedical field to produce devices and interfaces with transduction capability [192]. Chen et al. reported on a photocurable piezoelectric ink suitable for additive manufacturing [193]. In the bioprinting research, additional factors must be investigated, as the optimal printing parameters for manufacturing a 3D architecture could not be suitable for cell survival, thus pointing out that the rheological properties of the bioink are fundamental [194]. Hydrogel composition together with printing parameters strongly affect printability in terms of desired shape resolution, as demonstrated using pure alginate or alginate with gelatin and methyl-cellulose [195]. Moreover, the solvent used for hydrogel formation, the resultant viscosity, the applied pressure and temperature, as well as the nozzle size and geometrical factors of the printing head all influence cell viability, due to the shear stress experienced by the cells upon extrusion, which represents a key factor [196]. Shear-thinning properties are crucial for keeping bioink shape fidelity and cell viability. Preliminary studies have demonstrated the bioprintability by different 3D printing methods of thermosensitive p(NIPAAm-AA) hydrogel, proposed as a vascularized skin substitute [197]. In similar fashion, a number of smart materials are reported to be 3D printed every day, thus suggesting intriguing opportunities for 4D (bio-)printing [15,198]. As such, a great effort still regards the exact spatial and temporal control of the property change in smart material printing, which includes novel studies via computational modeling [199].

Controlled drug delivery has a high potential to improve drug efficacy, as well as personalized and local drug administration. Having a controlled delivery reduces the patient's pharmacokinetic variability inherent to oral and intravenous applications. One of the options is the use of magnetic nanoparticles capable of incorporating a reasonably high weight fraction of the drugs, of forming a stable suspension in biocompatible, biodegradable aqueous media, and of not being rapidly eliminated in the bloodstream. The main advantage of using these nanoparticles relies on the exploitation of magnetic stimuli to achieve zonal confinement and administration of drugs to be remotely directed [200].

Finally, 4D (bio-)printing allows the spatial distribution of different materials to be controlled, which can be self-fold or self-unfold, thus obtaining the encapsulation and release of drugs or cells in a programmable way [24]. For example, small droplets of oil that encapsulate aqueous droplets called "multisomes" can be printed in water [201]; these droplets adhere to each other forming bilayers. After being stimulated with temperature, the components in the droplets can be released [24]. Other macroscale materials with self-morphing [202], and self-folding properties have shown promise in tissue regeneration [203-205].

Due to the almost infinite possibilities of manufacturing all these smart polymers and composites in 3D structures, 4D (bio-)printing offers an unprecedented tunability of interfacing with healthy and pathologic tissue microenvironments, which is essential in a nonstatic and complex system like the human body. The next generation devices are expected both to sense and respond to local changes in live tissue, including the ability to communicate the occurring state (e.g., inflammation, infection, cancer, neurodegeneration) to the outside, thus enabling a therapy to be strictly monitored and inherently adjusted.

Until now, printable biomaterials that are sensitive to physical stimuli, such as moisture, temperature, electric and magnetic field, and light are limited, and most respond only to one stimulus. The search for new biomaterials must consider biocompatibility as the most crucial feature to achieve a full functionality [206]. Therefore, the development and translation of smart materials for $4 \mathrm{D}$ (bio-)printing technologies in biomedicine should be based on constant literature review, as well as on the implementation of key printing parameters. Easy to use, affordable, fully automated high-resolution bioprinters are greatly needed for this purpose [207]. It is expected that computational modeling and artificial intelligence will play significant roles in enabling a factual translation of this technology into real practice.

$4 \mathrm{D}$ (bio-)printing technique is opening new opportunities in biomedical engineering and will serve as a toolbox to approach medical problems by considering not only the body, but also the scaffold as dynamic systems, both changing with time and responding to varying conditions, including multiple 
stimuli. Such a dialogue seems to be necessary to transform $4 \mathrm{D}$ printing's great potential into feasible therapeutic options.

Author Contributions: Conceptualization, P.M. and S.D.; methodology, P.M., C.F., and D.R.; investigation, M.M. and B.A.; writing—original draft preparation, P.M., M.M., B.A., F.M., C.F., D.R. and S.D.; writing-review and editing, P.M., M.M., B.A., F.M., and S.D.; visualization, F.M.; supervision, P.M. and S.D.; project administration, P.M. and S.D.; funding acquisition, M.M. and S.D. All authors have read and agreed to the published version of the manuscript.

Funding: S.D. and B.A. acknowledge NANO-SPARKS project (MISTI funds, MIT-UNIPI 2016). M.M. was supported by the European Union's Horizon 2020 research and innovation program under the Marie Skłodowska-Curie grant agreement COLLHEAR no. 794614.

Conflicts of Interest: The authors declare no conflict of interest.

\section{References}

1. Miyoshi, H. Smart Design of Materials for Tissue Engineering. In Smart Materials for Tissue Engineering: Fundamental Principles; The Royal Society of Chemistry: London, UK, 2016; ISBN 9789533070797.

2. Langer, R.; Vacanti, J.P. Tissue engineering. Science 1993, 920-926. [CrossRef] [PubMed]

3. Chan, B.P.; Leong, K.W. Scaffolding in tissue engineering: General approaches and tissue-specific considerations. Eur. Spine J. 2008, 17. [CrossRef] [PubMed]

4. Hoffman, A.S. Stimuli-responsive polymers: Biomedical applications and challenges for clinical translation. Adv. Drug Deliv. Rev. 2013, 65, 10-16. [CrossRef] [PubMed]

5. Stuart, M.A.C.; Huck, W.T.S.; Genzer, J.; Müller, M.; Ober, C.; Stamm, M.; Sukhorukov, G.B.; Szleifer, I.; Tsukruk, V.V.; Urban, M.; et al. Emerging applications of stimuli-responsive polymer materials. Nat. Mater. 2010, 9, 101-113. [CrossRef] [PubMed]

6. Zhang, X.; Chen, L.; Lim, K.H.; Gonuguntla, S.; Lim, K.W.; Pranantyo, D.; Yong, W.P.; Yam, W.J.T.; Low, Z.; Teo, W.J.; et al. The Pathway to Intelligence: Using Stimuli-Responsive Materials as Building Blocks for Constructing Smart and Functional Systems. Adv. Mater. 2019, 31, 1804540. [CrossRef] [PubMed]

7. Sears, N.A.; Seshadri, D.R.; Dhavalikar, P.S.; Cosgriff-Hernandez, E. A Review of Three-Dimensional Printing in Tissue Engineering. Tissue Eng. Part B Rev. 2016. [CrossRef] [PubMed]

8. Morouço, P.G. The Usefulness of Direct Digital Manufacturing for Biomedical Applications. In Intensification of Biobased Processes; The Royal Society of Chemistry: London, UK, 2018; pp. 478-487.

9. Hull, C.W. Method of and Apparatus for Production of Three Dimensional Objects by Stereolithography. U.S. Patent No 5,236,637, 17 August 1993.

10. Hutmacher, D.W.; Schantz, T.; Zein, I.; Ng, K.W.; Teoh, S.H.; Tan, K.C. Mechanical properties and cell cultural response of polycaprolactone scaffolds designed and fabricated via fused deposition modeling. J. Biomed. Mater. Res. 2001, 55, 203-216. [CrossRef]

11. Mullen, L.; Stamp, R.C.; Brooks, W.K.; Jones, E.; Sutcliffe, C.J. Selective laser melting: A regular unit cell approach for the manufacture of porous, titanium, bone in-growth constructs, suitable for orthopedic applications. J. Biomed. Mater. Res. Part B Appl. Biomater. 2009, 89, 325-334. [CrossRef]

12. Nakamura, M.; Iwanaga, S.; Henmi, C.; Arai, K.; Nishiyama, Y. Biomatrices and biomaterials for future developments of bioprinting and biofabrication. Biofabrication 2010, 2, 014110. [CrossRef]

13. Castro, N.J.; Meinert, C.; Levett, P.; Hutmacher, D.W. Current developments in multifunctional smart materials for 3D/4D bioprinting. Curr. Opin. Biomed. Eng. 2017, 2, 67-75. [CrossRef]

14. Milazzo, M.; Contessi Negrini, N.; Scialla, S.; Marelli, B.; Farè, S.; Danti, S.; Buehler, M.J. Additive Manufacturing Approaches for Hydroxyapatite-Reinforced Composites. Adv. Funct. Mater. 2019, $29,1903055$. [CrossRef]

15. Khoo, Z.X.; Teoh, J.E.M.; Liu, Y.; Chua, C.K.; Yang, S.; An, J.; Leong, K.F.; Yeong, W.Y. 3D printing of smart materials: A review on recent progresses in 4D printing. Virtual Phys. Prototyp. 2015, 10, 103-122. [CrossRef]

16. Li, Y.-C.; Zhang, Y.S.; Akpek, A.; Shin, S.R.; Khademhosseini, A. 4D bioprinting: The next-generation technology for biofabrication enabled by stimuli-responsive materials. Biofabrication 2016, 9, 12001. [CrossRef] [PubMed] 
17. Ashammakhi, N.; Ahadian, S.; Zengjie, F.; Suthiwanich, K.; Lorestani, F.; Orive, G.; Ostrovidov, S.; Khademhosseini, A. Advances and future perspectives in 4D bioprinting. Biotechnol. J. 2018, 13, 1800148. [CrossRef]

18. Keriquel, V.; Oliveira, H.; Rémy, M.; Ziane, S.; Delmond, S.; Rousseau, B.; Rey, S.; Catros, S.; Amédée, J.; Guillemot, F.; et al. In situ printing of mesenchymal stromal cells, by laser-assisted bioprinting, for in vivo bone regeneration applications. Sci. Rep. 2017, 7, 1-10. [CrossRef]

19. Liu, F.; Wang, X. Synthetic Polymers for Organ 3D Printing. Polymers (Basel) 2020, 12, 1765. [CrossRef]

20. Vijayavenkataraman, S.; Fuh, J.Y.H.; Lu, W.F. 3D printing and 3D bioprinting in pediatrics. Bioengineering 2017, 4, 63. [CrossRef]

21. Groll, J.; Boland, T.; Blunk, T.; Burdick, J.A.; Cho, D.-W.; Dalton, P.D.; Derby, B.; Forgacs, G.; Li, Q.; Mironov, V.A.; et al. Biofabrication: Reappraising the definition of an evolving field. Biofabrication 2016, 8 , 13001. [CrossRef]

22. Leist, S.K.; Zhou, J. Current status of $4 \mathrm{D}$ printing technology and the potential of light-reactive smart materials as 4D printable materials. Virtual Phys. Prototyp. 2016, 2759, 1-14. [CrossRef]

23. Mandon, C.A.; Blum, L.J.; Marquette, C.A. 3D-4D printed objects: New bioactive material opportunities. Micromachines 2017, 8, 102. [CrossRef]

24. Gao, B.; Yang, Q.; Zhao, X.; Jin, G.; Ma, Y.; Xu, F. 4D bioprinting for biomedical applications. Trends Biotechnol. 2016, 34, 746-756. [CrossRef] [PubMed]

25. Morouço, P.; Lattanzi, W.; Alves, N. Four-dimensional bioprinting as a new era for tissue engineering and regenerative medicine. Front. Bioeng. Biotechnol. 2017, 5, 61. [CrossRef] [PubMed]

26. Momeni, F.M.; Mehdi Hassani, N.S.; Liu, X.; Ni, J. A review of 4D printing. Mater. Des. 2017, 122, 42-79. [CrossRef]

27. An, J.; Chua, C.K.; Mironov, V. A perspective on $4 \mathrm{D}$ bioprinting. Int. J. Bioprinting 2016, 2, 3-5. [CrossRef]

28. Moroni, L.; Boland, T.; Burdick, J.A.; De Maria, C.; Derby, B.; Forgacs, G.; Groll, J.; Li, Q.; Malda, J.; Mironov, V.A.; et al. Biofabrication: A guide to technology and terminology. Trends Biotechnol. 2018, 36, 384-402. [CrossRef]

29. Wang, S.; Lee, J.M.; Yeong, W.Y. Smart hydrogels for 3D bioprinting. Int. J. Bioprinting 2015, 1, 3-14. Available online: http://ijb.whioce.com/index.php/int-j-bioprinting/article/view/01005 (accessed on 23 October 2020). [CrossRef]

30. Negrini, N.C.; Bonetti, L.; Contili, L.; Farè, S. 3D printing of methylcellulose-based hydrogels. Bioprinting 2018, 10, e00024. [CrossRef]

31. Negrini, N.C.; Celikkin, N.; Tarsini, P.; Farè, S.; Święszkowski, W. Three-dimensional printing of chemically crosslinked gelatin hydrogels for adipose tissue engineering. Biofabrication 2020, 12, 25001. [CrossRef]

32. Ikegami, T.; Maehara, Y. Transplantation: 3D printing of the liver in living donor liver transplantation. Nat. Rev. Gastroenterol. Hepatol. 2013, 10, 697-698. [CrossRef]

33. Valverde, I.; Gomez, G.; Suarez-mejias, C.; Hosseinpour, A.; Hazekamp, M.; Roest, A.; Vazquez-jimenez, J.F.; El-rassi, I.; Uribe, S.; Gomez-cia, T. 3D printed cardiovascular models for surgical planning in complex congenital heart diseases. J. Cardiovasc. Magn. Reson. 2015, 17, P196. [CrossRef]

34. Gao, G.; Cui, X. Three-dimensional bioprinting in tissue engineering and regenerative medicine. Biotechnol. Lett. 2016, 38, 203-211. [CrossRef] [PubMed]

35. Wang, J.H.-C. Mechanobiology of tendon. J. Biomech. 2006, 39, 1563-1582. [CrossRef] [PubMed]

36. Milazzo, M.; Jung, G.S.; Danti, S.; Buehler, M.J. Mechanics of mineralized collagen fibrils upon transient loads. ACS Nano 2020, 14, 8307-8316. [CrossRef] [PubMed]

37. Milazzo, M.; Jung, G.S.; Danti, S.; Buehler, M.J. Wave propagation and energy dissipation in collagen molecules. ACS Biomater. Sci. Eng. 2020, 6, 1367-1374. [CrossRef]

38. Ekwueme, E.C.; Patel, J.M.; Freeman, J.W.; Danti, S. Applications of bioresorbable polymers in the skeletal systems (cartilages, tendons, bones). In Bioresorbable Polymers for Biomedical Applications; Elsevier: Amsterdam, The Netherlands, 2017; pp. 391-422.

39. Zhu, L.; Qiu, J.; Sakai, E. A high modulus hydrogel obtained from hydrogen bond reconstruction and its application in vibration damper. RSC Adv. 2017, 7, 43755-43763. [CrossRef]

40. Meng, H.; Li, G. A review of stimuli-responsive shape memory polymer composites. Polymer (United Kingdom) 2013, 54, 2199-2221. [CrossRef] 
41. Roy, D.; Cambre, J.N.; Sumerlin, B.S. Future perspectives and recent advances in stimuli-responsive materials. Prog. Polym. Sci. 2010, 35, 278-301. [CrossRef]

42. Morouço, P.; Gil, J. Four-Dimensional Bioprinting for Regenerative Medicine: Mechanisms to Induce Shape Variation and Potential Applications. Innovations 2019, 3, 36-43. [CrossRef]

43. Koetting, M.C.; Peters, J.T.; Steichen, S.D.; Peppas, N.A. Stimulus-responsive hydrogels: Theory, modern advances, and applications. Mater. Sci. Eng. R Rep. 2015, 93, 1-49. [CrossRef]

44. Bertassoni, L.E.; Cardoso, J.C.; Manoharan, V.; Cristino, A.L.; Bhise, N.S.; Araujo, W.A.; Zorlutuna, P.; Vrana, N.E.; Ghaemmaghami, A.M.; Dokmeci, M.R.; et al. Direct-write bioprinting of cell-laden methacrylated gelatin hydrogels. Biofabrication 2014, 6, 024105. [CrossRef]

45. Chang, C.C.; Boland, E.D.; Williams, S.K.; Hoying, J.B. Direct-write bioprinting three-dimensional biohybrid systems for future regenerative therapies. J. Biomed. Mater. Res. Part B Appl. Biomater. 2011. [CrossRef] [PubMed]

46. Woodfield, T.; Lim, K.; Morouço, P.; Levato, R.; Malda, J.; Melchels, F. Biofabrication in Tissue Engineering. In Comprehensive Biomaterials II; Springer International Publishing: Cham, Switzerland, 2017; pp. 236-266, ISBN 9780128035818.

47. Dai, M.; Picot, O.T.; Verjans, J.M.N.; De Haan, L.T.; Schenning, A.P.H.J.; Peijs, T.; Bastiaansen, C.W.M. Humidity-responsive bilayer actuators based on a liquid-crystalline polymer network. ACS Appl. Mater. Interfaces 2013, 5, 4945-4950. [CrossRef] [PubMed]

48. Zhang, L.; Liang, H.; Jacob, J.; Naumov, P. Photogated humidity-driven motility. Nat. Commun. 2015, 6, 7429. [CrossRef] [PubMed]

49. Liu, Y.; Li, Y.; Yang, G.; Zheng, X.; Zhou, S. Multi-stimulus-responsive shape-memory polymer nanocomposite network cross-linked by cellulose nanocrystals. ACS Appl. Mater. Interfaces 2015, 7, 4118-4126. [CrossRef]

50. Torbati, A.H.; Mather, P.T. A hydrogel-forming liquid crystalline elastomer exhibiting soft shape memory. J. Polym. Sci. Part B Polym. Phys. 2016, 54, 38-52. [CrossRef]

51. Lv, C.; Sun, X.-C.; Xia, H.; Yu, Y.-H.; Wang, G.; Cao, X.-W.; Li, S.-X.; Wang, Y.-S.; Chen, Q.-D.; $\mathrm{Yu}, \mathrm{Y}$.-D. Humidity-responsive actuation of programmable hydrogel microstructures based on 3D printing. Sens. Actuators B Chem. 2018, 259, 736-744. [CrossRef]

52. Lv, C.; Xia, H.; Shi, Q.; Wang, G.; Wang, Y.; Chen, Q.; Zhang, Y.; Liu, L.; Sun, H. Sensitively Humidity-Driven Actuator Based on Photopolymerizable PEG-DA Films. Adv. Mater. Interfaces 2017, 4. [CrossRef]

53. Jamal, M.; Kadam, S.S.; Xiao, R.; Jivan, F.; Onn, T.; Fernandes, R.; Nguyen, T.D.; Gracias, D.H. Bio-Origami Hydrogel Scaffolds Composed of Photocrosslinked PEG Bilayers. Adv. Healthc. Mater. 2013, 2, 1142-1150. [CrossRef]

54. Ma, M.; Guo, L.; Anderson, D.G.; Langer, R. Bio-inspired polymer composite actuator and generator driven by water gradients. Science 2013, 339, 186-189. [CrossRef]

55. Zhang, K.; Geissler, A.; Standhardt, M.; Mehlhase, S.; Gallei, M.; Chen, L.; Thiele, C.M. Moisture-responsive films of cellulose stearoyl esters showing reversible shape transitions. Sci. Rep. 2015, 5, 11011. [CrossRef]

56. Wang, G.; Xia, H.; Sun, X.-C.; Lv, C.; Li, S.-X.; Han, B.; Guo, Q.; Shi, Q.; Wang, Y.-S.; Sun, H.-B. Actuator and generator based on moisture-responsive PEDOT: PSS/PVDF composite film. Sens. Actuators B Chem. 2018, 255, 1415-1421. [CrossRef]

57. Raviv, D.; Zhao, W.; McKnelly, C.; Papadopoulou, A.; Kadambi, A.; Shi, B.; Hirsch, S.; Dikovsky, D.; Zyracki, M.; Olguin, C. Active printed materials for complex self-evolving deformations. Sci. Rep. 2014, 4, 7422. [CrossRef] [PubMed]

58. Gladman, A.S.; Matsumoto, E.A.; Nuzzo, R.G.; Mahadevan, L.; Lewis, J.A. Biomimetic 4D printing. Nat. Mater. 2016, 15, 413. [CrossRef] [PubMed]

59. Wu, A.; Lu, F.; Zhao, M.; Sun, N.; Shi, L.; Zheng, L. Photo and Humidity Responsive Mesoporous Poly (ionic Liquid) Membrane for Selective Dye Adsorption. ChemistrySelect 2017, 2, 1878-1884. [CrossRef]

60. EPA, U.S. United States Environmental Protection Agency. Qual. Assur. Guid. Doc. Qual. Assur. Proj. Plan PM Ambient Air 2001, 2. Available online: https://www3.epa.gov/ttnamtil/files/ambient/pm25/qa/Final\% 20Handbook\%20Document\%201_17.pdf (accessed on 23 October 2020).

61. Zhou, S.; Deng, X.; Yang, H. Biodegradable poly( $\varepsilon$-caprolactone)-poly(ethylene glycol) block copolymers: Characterization and their use as drug carriers for a controlled delivery system. Biomaterials 2003, 24, 3563-3570. [CrossRef] 
62. AndrÃ, J.-C. From Additive Manufacturing to 3D/4D Printing: Breakthrough Innovations: Programmable Material, 4D Printing and Bio-Printing; John Wiley \& Sons: Hoboken, NJ, USA, 2017; ISBN 1119482771.

63. Zhang, X.; Pint, C.L.; Lee, M.H.; Schubert, B.E.; Jamshidi, A.; Takei, K.; Ko, H.; Gillies, A.; Bardhan, R.; Urban, J.J. Optically-and thermally-responsive programmable materials based on carbon nanotube-hydrogel polymer composites. Nano Lett. 2011, 11, 3239-3244. [CrossRef]

64. Romano, L.; Portone, L.; Coltelli, M.B.; Patti, F.; Saija, R.; Iatì, M.A.; Gallone, G.; Lazzeri, A.; Danti, S.; Marago, O.; et al. Intelligent non-colorimetric indicators for the perishable supply chain by non-wovens with photo-programmed thermal response. Nat. Commun. 2020, 11, 5991. [CrossRef]

65. Cabane, E.; Zhang, X.; Langowska, K.; Palivan, C.G.; Meier, W.; Cabane, E.; Zhang, X.; Langowska, K.; Palivan, C.G.; Meier, W. Stimuli-responsive polymers and their applications in nanomedicine. Biointerphases 2012, 7, 1-27. [CrossRef]

66. Bakarich, S.E.; Gorkin, R., III; Panhuis, M.I.; Spinks, G.M. 4D Printing with Mechanically Robust, Thermally Actuating Hydrogels. Macromol. Rapid Commun. 2015, 36, 1211-1217. [CrossRef]

67. Peppas, N.A.; Bures, P.; Leobandung, W.; Ichikawa, H. Hydrogels in pharmaceutical formulations. Eur. J. Pharm. Biopharm. 2000, 50, 27-46. [CrossRef]

68. Wang, X.; Sun, Y.; Peng, C.; Luo, H.; Wang, R.; Zhang, D. Transitional Suspensions Containing Thermosensitive Dispersant for Three-Dimensional Printing. ACS Appl. Mater. Interfaces 2015, 7, 26131-26136. [CrossRef] [PubMed]

69. Kim, S.; Kim, J.H.; Jeon, O.; Kwon, I.C.; Park, K. Engineered polymers for advanced drug delivery. Eur. J. Pharm. Biopharm. 2009, 71, 420-430. [CrossRef] [PubMed]

70. Stoychev, G.; Puretskiy, N.; Ionov, L. Self-folding all-polymer thermoresponsive microcapsules. Soft Matter 2011, 7, 3277. [CrossRef]

71. Luo, R.; Wu, J.; Dinh, N.-D.; Chen, C.-H. Gradient porous elastic hydrogels with shape-memory property and anisotropic responses for programmable locomotion. Adv. Funct. Mater. 2015, 25, 7272-7279. [CrossRef]

72. Xu, X.; Liu, Y.; Fu, W.; Yao, M.; Ding, Z.; Xuan, J.; Li, D.; Wang, S.; Xia, Y.; Cao, M. Poly (N-isopropylacrylamide)-based thermoresponsive composite hydrogels for biomedical applications. Polymers (Basel) 2020, 12, 580. [CrossRef]

73. Chastek, T.T.; Wadajkar, A.; Nguyen, K.T.; Hudson, S.D.; Chastek, T.Q. Polyglycol-templated synthesis of poly(N-isopropyl acrylamide) microgels with improved biocompatibility. Colloid Polym. Sci. 2010, 288, 105-114. [CrossRef]

74. Cooperstein, M.A.; Canavan, H.E. Assessment of cytotoxicity of (N-isopropyl acrylamide ) and Poly (N-isopropyl acrylamide )—Coated surfaces. Biointerphases 2013, 8, 1-12. [CrossRef]

75. Sarkar, J.; Kumari, J.; Tonello, J.M.; Kamihira, M.; Kumar, A. Enhanced hepatic functions of genetically modified mouse hepatoma cells by spheroid culture for drug toxicity screening. Biotechnol. J. 2017, 12, 1700274. [CrossRef]

76. Ricci, C.; Moroni, L.; Danti, S. Cancer tissue engineering-new perspectives in understanding the biology of solid tumours-a critical review. OA Tissue Eng. 2013, 1, 1-4. [CrossRef]

77. Chew, S.A.; Moscato, S.; George, S.; Azimi, B.; Danti, S. Liver cancer: Current and future trends using biomaterials. Cancers (Basel) 2019, 11, 2026. [CrossRef] [PubMed]

78. Doorty, K.B.; Golubeva, T.A.; Gorelov, A.V.; Rochev, Y.A.; Allen, L.T.; Dawson, K.A.; Gallagher, W.M.; Keenan, A.K. Poly (N-isopropylacrylamide) co-polymer films as potential vehicles for delivery of an antimitotic agent to vascular smooth muscle cells. Cardiovasc. Pathol. 2003, 12, 105-110. [CrossRef]

79. Yang, Z.; Zhang, W.; Zou, J.; Shi, W. Synthesis and thermally responsive characteristics of dendritic poly (ether-amide) grafting with PNIPAAm and PEG. Polymer (Guildf) 2007, 48, 931-938. [CrossRef]

80. Vihola, H.; Laukkanen, A.; Valtola, L.; Tenhu, H.; Hirvonen, J. Cytotoxicity of thermosensitive polymers poly(N-isopropylacrylamide), poly(N-vinylcaprolactam) and amphiphilically modified poly(N-vinylcaprolactam). Biomaterials 2005, 26, 3055-3064. [CrossRef] [PubMed]

81. Xiao, R.Z.; Zeng, Z.W.; Zhou, G.L.; Wang, J.J.; Li, F.Z.; Wang, A.M. Recent advances in PEG-PLA block copolymer nanoparticles. Int. J. Nanomed. 2010, 5, 1057-1065. [CrossRef]

82. Redhead, M.; Mantovani, G.; Nawaz, S.; Carbone, P.; Gorecki, D.C.; Alexander, C.; Bosquillon, C. Relationship between the affinity of PEO-PPO-PEO block copolymers for biological membranes and their cellular effects. Pharm. Res. 2012, 29, 1908-1918. [CrossRef] 
83. Sosnik, A.; Cohn, D. Ethoxysilane-capped PEO-PPO-PEO triblocks: A new family of reverse thermo-responsive polymers. Biomaterials 2004, 25, 2851-2858. [CrossRef]

84. Cho, H.; Kwon, G.S. Thermosensitive poly-(d, l-lactide-co-glycolide)-block-poly (ethylene glycol)-blockpoly-(d, 1-lactide-co-glycolide) hydrogels for multi-drug delivery. J. Drug Target. 2014, 22, 669-677. [CrossRef]

85. Magdanz, V.; Stoychev, G.; Ionov, L.; Sanchez, S.; Schmidt, O.G. Stimuli-responsive microjets with reconfigurable shape. Angew. Chemie 2014, 126, 2711-2715. [CrossRef]

86. Ohya, S.; Sonoda, H.; Nakayama, Y.; Matsuda, T. The potential of poly (N-isopropylacrylamide) (PNIPAM)-grafted hyaluronan and PNIPAM-grafted gelatin in the control of post-surgical tissue adhesions. Biomaterials 2005, 26, 655-659. [CrossRef]

87. Liu, Y.; Meng, L.; Lu, X.; Zhang, L.; He, Y. Thermo and $\mathrm{pH}$ sensitive fluorescent polymer sensor for metal cations in aqueous solution. Polym. Adv. Technol. 2008, 19, 137-143. [CrossRef]

88. Liang, X.; Kozlovskaya, V.; Chen, Y.; Zavgorodnya, O.; Kharlampieva, E. Thermosensitive multilayer hydrogels of poly (N-vinylcaprolactam) as nanothin films and shaped capsules. Chem. Mater. 2012, 24, 3707-3719. [CrossRef] [PubMed]

89. Na, K.; Lee, K.H.; Lee, D.H.; Bae, Y.H. Biodegradable thermo-sensitive nanoparticles from poly (L-lactic acid)/poly (ethylene glycol) alternating multi-block copolymer for potential anti-cancer drug carrier. Eur. J. Pharm. Sci. 2006, 27, 115-122. [CrossRef] [PubMed]

90. Cohn, D.; Lando, G.; Sosnik, A.; Garty, S.; Levi, A. PEO-PPO—PEO-based poly (ether ester urethane) s as degradable reverse thermo-responsive multiblock copolymers. Biomaterials 2006, 27, 1718-1727. [CrossRef]

91. Yu, K.; Ritchie, A.; Mao, Y.; Dunn, M.L.; Qi, H.J. Controlled sequential shape changing components by 3D printing of shape memory polymer multimaterials. Procedia IUTAM 2015, 12, 193-203. [CrossRef]

92. Ge, Q.; Sakhaei, A.H.; Lee, H.; Dunn, C.K.; Fang, N.X.; Dunn, M.L. Multimaterial 4D printing with tailorable shape memory polymers. Sci. Rep. 2016, 6, 31110. [CrossRef]

93. Contessi, N.; Altomare, L.; Filipponi, A.; Farè, S. Thermo-responsive properties of methylcellulose hydrogels for cell sheet engineering. Mater. Lett. 2017, 207, 157-160. [CrossRef]

94. Pillay, V.; Tsai, T.-S.; Choonara, Y.E.; du Toit, L.C.; Kumar, P.; Modi, G.; Naidoo, D.; Tomar, L.K.; Tyagi, C.; Ndesendo, V.M.K. A review of integrating electroactive polymers as responsive systems for specialized drug delivery applications. J. Biomed. Mater. Res. Part A 2014, 102, 2039-2054. [CrossRef]

95. Sista, P.; Ghosh, K.; Martinez, J.S.; Rocha, R.C. Polythiophenes in biological applications. J. Nanosci. Nanotechnol. 2014, 14, 250-272. [CrossRef]

96. Herold, B.C.; Bourne, N.; Marcellino, D.; Kirkpatrick, R.; Mosoian, A.; Klotman, M.; Strauss, D.; Anderson, R.; Zanenveld, L.; Cooper, M.; et al. Polystyrene sulfonate is a safe and effective candidate topical antimicrobial for the prevention of sexually transmitted diseases. Pediatr. Res. 1999, 45, 163. [CrossRef]

97. Alzari, V.; Nuvoli, D.; Sanna, R.; Peponi, L.; Piccinini, M.; Bon, S.B.; Marceddu, S.; Valentini, L.; Kenny, J.M.; Mariani, A. Multistimuli-responsive hydrogels of poly (2-acrylamido-2-methyl-1-propanesulfonic acid) containing graphene. Colloid Polym. Sci. 2013, 291, 2681-2687. [CrossRef]

98. D'Emanuele, A.; Staniforth, J.N. An electrically modulated drug delivery device: I. Pharm. Res. 1991, 8, 913-918. [CrossRef] [PubMed]

99. Niu, X.; Rouabhia, M.; Chiffot, N.; King, M.W.; Zhang, Z. An electrically conductive 3D scaffold based on a nonwoven web of poly (1-lactic acid) and conductive poly (3, 4-ethylenedioxythiophene). J. Biomed. Mater. Res. Part A 2015, 103, 2635-2644. [CrossRef] [PubMed]

100. Duc, C.; Vlandas, A.; Malliaras, G.G.; Senez, V. Study of the electro-responsiveness and surface texturing of PEDOT: PSS for smart MEMS interface applications. In Proceedings of the 2017 19th International Conference on Solid-State Sensors, Actuators and Microsystems (TRANSDUCERS), Kaohsiung, Taiwan, 18-22 June 2017; pp. 1391-1394.

101. Pires, F.; Ferreira, Q.; Rodrigues, C.A.V.; Morgado, J.; Ferreira, F.C. Neural stem cell differentiation by electrical stimulation using a cross-linked PEDOT substrate: Expanding the use of biocompatible conjugated conductive polymers for neural tissue engineering. Biochim. Biophys. Acta (BBA) General Subj. 2015, 1850, 1158-1168. [CrossRef] [PubMed]

102. Srivastava, N.; Venugopalan, V.; Divya, M.S.; Rasheed, V.A.; James, J.; Narayan, K.S. Neuronal differentiation of embryonic stem cell derived neuronal progenitors can be regulated by stretchable conducting polymers. Tissue Eng. Part A 2013, 19, 1984-1993. [CrossRef] [PubMed] 
103. Liu, F.; Urban, M.W. Recent advances and challenges in designing stimuli-responsive polymers. Prog. Polym. Sci. 2010, 35, 3-23. [CrossRef]

104. Scialla, S.; Barca, A.; Palazzo, B.; D’Amora, U.; Russo, T.; Gloria, A.; De Santis, R.; Verri, T.; Sannino, A.; Ambrosio, L.; et al. Bioactive Chitosan-Based Scaffolds with Improved Properties Induced by Dextran-Grafted Nano-Maghemite and L-Arginine Amino Acid. J. Biomed. Mater. Res. Part A 2019, 107, 1244-1252. [CrossRef]

105. Szabo, D.; Szeghy, G.; Zrinyi, M. Shape transition of magnetic field sensitive polymer gels. Macromolecules 1998, 31, 6541-6548. [CrossRef]

106. Zrinyi, M. Intelligent polymer gels controlled by magnetic fields. Colloid Polym. Sci. 2000, 278, 98-103. [CrossRef]

107. Bowles, S.E.; Wu, W.; Kowalewski, T.; Schalnat, M.C.; Davis, R.J.; Pemberton, J.E.; Shim, I.; Korth, B.D.; Pyun, J. Magnetic assembly and pyrolysis of functional ferromagnetic colloids into one-dimensional carbon nanostructures. J. Am. Chem. Soc. 2007, 129, 8694-8695. [CrossRef]

108. Giani, G.; Fedi, S.; Barbucci, R. Hybrid magnetic hydrogel: A potential system for controlled drug delivery by means of alternating magnetic fields. Polymers (Basel) 2012, 4, 1157-1169. [CrossRef]

109. Brugger, B.; Richtering, W. Magnetic, thermosensitive microgels as stimuli-responsive emulsifiers allowing for remote control of separability and stability of oil in water-emulsions. Adv. Mater. 2007, 19, 2973-2978. [CrossRef]

110. Xulu, P.M.; Filipcsei, G.; Zrinyi, M. Preparation and responsive properties of magnetically soft poly (N-isopropylacrylamide) gels. Macromolecules 2000, 33, 1716-1719. [CrossRef]

111. Zhang, J.; Xu, S.; Kumacheva, E. Polymer microgels: Reactors for semiconductor, metal, and magnetic nanoparticles. J. Am. Chem. Soc. 2004, 126, 7908-7914. [CrossRef]

112. Zhao, X.; Kim, J.; Cezar, C.A.; Huebsch, N.; Lee, K.; Bouhadir, K.; Mooney, D.J. Active scaffolds for on-demand drug and cell delivery. Proc. Natl. Acad. Sci. USA 2011, 108, 67-72. [CrossRef]

113. Czaun, M.; Hevesi, L.; Takafuji, M.; Ihara, H. A novel approach to magneto-responsive polymeric gels assisted by iron nanoparticles as nano cross-linkers. Chem. Commun. 2008, 2124-2126. [CrossRef]

114. Pašukonienė, V.; Mlynska, A.; Steponkienè, S.; Poderys, V.; Matulionytė, M.; Karabanovas, V.; Statkutė, U.; Purvinienè, R.; Kraśko, J.A.; Jagminas, A.; et al. Accumulation and biological effects of cobalt ferrite nanoparticles in human pancreatic and ovarian cancer cells. Medicina (B. Aires) 2014, 50, 237-244. [CrossRef]

115. Li, Y.; Huang, G.; Zhang, X.; Li, B.; Chen, Y.; Lu, T.; Lu, T.J.; Xu, F. Magnetic hydrogels and their potential biomedical applications. Adv. Funct. Mater. 2013, 23, 660-672. [CrossRef]

116. Della Giustina, G.; Gandin, A.; Brigo, L.; Panciera, T.; Giulitti, S.; Sgarbossa, P.; D’Alessandro, D.; Trombi, L.; Danti, S.; Brusatin, G. Polysaccharide hydrogels for multiscale 3D printing of pullulan scaffolds. Mater. Des. 2019, 165, 107566. [CrossRef]

117. Yavuz, M.S.; Cheng, Y.; Chen, J.; Cobley, C.M.; Zhang, Q.; Rycenga, M.; Xie, J.; Kim, C.; Song, K.H.; Schwartz, A.G.; et al. Gold nanocages covered by smart polymers for controlled release with near-infrared light. Nat. Mater. 2009, 8, 935-939. [CrossRef]

118. D'Acunto, M.; Trombi, L.; D'Alessandro, D.; Danti, S. Raman spectroscopy of osteosarcoma cells. Phys. Biol. 2018, 16, 16007. [CrossRef] [PubMed]

119. Huang, C.; Lv, J.; Tian, X.; Wang, Y.; Yu, Y.; Liu, J. Miniaturized swimming soft robot with complex movement actuated and controlled by remote light signals. Sci. Rep. 2015, 5, 1-8. [CrossRef] [PubMed]

120. Ichimura, K.; Oh, S.-K.; Nakagawa, M. Light-driven motion of liquids on a photoresponsive surface. Science 2000, 288, 1624-1626. [CrossRef] [PubMed]

121. Mahimwalla, Z. Characterization of Photo-Induced Mechanical Responses in Azobenzene Polymers; McGill University Libraries: Montreal, QC, Canada, 2013.

122. Wang, J.; Sun, L.; Zou, M.; Gao, W.; Liu, C.; Shang, L.; Gu, Z.; Zhao, Y. Bioinspired shape-memory graphene film with tunable wettability. Sci. Adv. 2017, 3, e1700004. [CrossRef]

123. Yoshida, M.; Lahann, J. Smart nanomaterials. ACS Nano 2008, 2, 1101-1107. [CrossRef]

124. Gumbley, P.; Koylu, D.; Thomas, S.W., III. Photoresponsive polymers containing nitrobenzyl esters via ring-opening metathesis polymerization. Macromolecules 2011, 44, 7956-7961. [CrossRef]

125. Zakrevskyy, Y.; Cywinski, P.; Cywinska, M.; Paasche, J.; Lomadze, N.; Reich, O.; Löhmannsröben, H.-G.; Santer, S. Interaction of photosensitive surfactant with DNA and poly acrylic acid. J. Chem. Phys. 2014, 140,01B613_1. [CrossRef] 
126. Konak, C.; Kopeckova, P.; Kopecek, J. Photoregulated association of N-(2-hydroxypropyl) methacrylamide copolymers with azobenzene-containing side chains. Macromolecules 1992, 25, 5451-5456. [CrossRef]

127. Sugiyama, K.; Sono, K. Characterization of photo-and thermoresponsible amphiphilic copolymers having azobenzene moieties as side groups. J. Appl. Polym. Sci. 2001, 81, 3056-3063. [CrossRef]

128. Cao, P.-F.; Mangadlao, J.D.; Advincula, R.C. Stimuli-responsive polymers and their potential applications in oil-gas industry. Polym. Rev. 2015, 55, 706-733. [CrossRef]

129. Motornov, M.; Roiter, Y.; Tokarev, I.; Minko, S. Stimuli-responsive nanoparticles, nanogels and capsules for integrated multifunctional intelligent systems. Prog. Polym. Sci. 2010, 35, 174-211. [CrossRef]

130. Giustina, G.D.; Giulitti, S.; Brigo, L.; Zanatta, M.; Tromayer, M.; Liska, R.; Elvassore, N.; Brusatin, G. Hydrogel with Orthogonal Reactive Units: 2D and 3D Cross-Linking Modulation. Macromol. Rapid Commun. 2017, 38, 1600570. [CrossRef] [PubMed]

131. Mohamed, R.R.; Elella, M.H.A.; Sabaa, M.W. Cytotoxicity and metal ions removal using antibacterial biodegradable hydrogels based on N-quaternized chitosan/poly (acrylic acid). Int. J. Biol. Macromol. 2017, 98, 302-313. [CrossRef] [PubMed]

132. Oerlemans, C.; Bult, W.; Bos, M.; Storm, G.; Nijsen, J.F.W.; Hennink, W.E. Polymeric micelles in anticancer therapy: Targeting, imaging and triggered release. Pharm. Res. 2010, 27, 2569-2589. [CrossRef]

133. Shimoboji, T.; Ding, Z.L.; Stayton, P.S.; Hoffman, A.S. Photoswitching of ligand association with a photoresponsive polymer- protein conjugate. Bioconjug. Chem. 2002, 13, 915-919. [CrossRef]

134. Lee, M.-J.; Jung, D.-H.; Han, Y.-K. Photo-responsive polymers and their applications to optical memory. Mol. Cryst. Liq. Cryst. 2006, 444, 41-50. [CrossRef]

135. Babin, J.; Pelletier, M.; Lepage, M.; Allard, J.-F.; Morris, D.; Zhao, Y. A new two-photon-sensitive block copolymer nanocarrier. Angew. Chem. Int. Ed. 2009, 48, 3329-3332. [CrossRef]

136. Jiang, J.; Tong, X.; Zhao, Y. A new design for light-breakable polymer micelles. J. Am. Chem. Soc. 2005, 127, 8290-8291. [CrossRef]

137. Zhao, Y. Rational design of light-controllable polymer micelles. Chem. Rec. 2007, 7, 286-294. [CrossRef]

138. Choi, H.-J.; Montemagno, C.D. Artificial organelle: ATP synthesis from cellular mimetic polymersomes. Nano Lett. 2005, 5, 2538-2542. [CrossRef]

139. Amiji, M.; Tailor, R.; Ly, M.-K.; Goreham, J. Gelatin-poly (ethylene oxide) semi-interpenetrating polymer network with $\mathrm{pH}$-sensitive swelling and enzyme-degradable properties for oral drug delivery. Drug Dev. Ind. Pharm. 1997, 23, 575-582. [CrossRef]

140. Bilia, A.; Carelli, V.; Di Colo, G.; Nannipieri, E. In vitro evaluation of a pH-sensitive hydrogel for control of GI drug delivery from silicone-based matrices. Int. J. Pharm. 1996, 130, 83-92. [CrossRef]

141. Bonina, P.; Petrova, T.S.; Manolova, N. pH-sensitive hydrogels composed of chitosan and polyacrylamide-preparation and properties. J. Bioact. Compat. Polym. 2004, 19, 101-116. [CrossRef]

142. Ferreira, L.; Vidal, M.M.; Gil, M.H. Evaluation of poly (2-hydroxyethyl methacrylate) gels as drug delivery systems at different $\mathrm{pH}$ values. Int. J. Pharm. 2000, 194, 169-180. [CrossRef]

143. Gupta, P.; Vermani, K.; Garg, S. Hydrogels: From controlled release to $\mathrm{pH}$-responsive drug delivery. Drug Discov. Today 2002, 7, 569-579. [CrossRef]

144. Mishra, R.K.; Ramasamy, K.; Majeed, A.B.A. pH-responsive poly (DMAPMA-co-HEMA)-based hydrogels for prolonged release of 5-fluorouracil. J. Appl. Polym. Sci. 2012, 126, E98-E107. [CrossRef]

145. Patel, V.R.; Amiji, M.M. Preparation and characterization of freeze-dried chitosan-poly (ethylene oxide) hydrogels for site-specific antibiotic delivery in the stomach. Pharm. Res. 1996, 13, 588-593. [CrossRef]

146. Raafat, A.I. Gelatin based pH-sensitive hydrogels for colon-specific oral drug delivery: Synthesis, characterization, and in vitro release study. J. Appl. Polym. Sci. 2010, 118, 2642-2649. [CrossRef]

147. Sethuraman, V.A.; Na, K.; Bae, Y.H. pH-responsive sulfonamide/PEI system for tumor specific gene delivery: An in vitro study. Biomacromolecules 2006, 7, 64-70. [CrossRef]

148. Shantha, K.L.; Harding, D.R.K. Preparation and in-vitro evaluation of poly [N-vinyl-2pyrrolidone-polyethylene glycol diacrylate]-chitosan interpolymeric $\mathrm{pH}$-responsive hydrogels for oral drug delivery. Int. J. Pharm. 2000, 207, 65-70. [CrossRef]

149. Webber, G.B.; Wanless, E.J.; Bütün, V.; Armes, S.P.; Biggs, S. Self-organized monolayer films of stimulus-responsive micelles. Nano Lett. 2002, 2, 1307-1313. [CrossRef]

150. Şen, M.; Uzun, C.; Güven, O. Controlled release of terbinafine hydrochloride from $\mathrm{pH}$ sensitive poly (acrylamide/maleic acid) hydrogels. Int. J. Pharm. 2000, 203, 149-157. 
151. Wright, D.B.; Patterson, J.P.; Pitto-Barry, A.; Cotanda, P.; Chassenieux, C.; Colombani, O.; O’Reilly, R.K. Tuning the aggregation behavior of $\mathrm{pH}$-responsive micelles by copolymerization. Polym. Chem. 2015, 6, 2761-2768. [CrossRef]

152. Battogtokh, G.; Ko, Y.T. Active-targeted pH-responsive albumin-photosensitizer conjugate nanoparticles as theranostic agents. J. Mater. Chem. B 2015, 3, 9349-9359. [CrossRef] [PubMed]

153. Abbas, G.; Hanif, M.; Khan, M.A. pH responsive alginate polymeric rafts for controlled drug release by using box behnken response surface design. Des. Monomers Polym. 2017, 20,1-9. [CrossRef] [PubMed]

154. Feng, W.; Nie, W.; He, C.; Zhou, X.; Chen, L.; Qiu, K.; Wang, W.; Yin, Z. Effect of pH-responsive alginate/chitosan multilayers coating on delivery efficiency, cellular uptake and biodistribution of mesoporous silica nanoparticles based nanocarriers. ACS Appl. Mater. Interfaces 2014, 6, 8447-8460. [CrossRef] [PubMed]

155. Serres, A.; Baudyš, M.; Kim, S.W. Temperature and $\mathrm{pH}$-sensitive polymers for human calcitonin delivery. Pharm. Res. 1996, 13, 196-201. [CrossRef]

156. Zhou, J.; Wang, L.; Ma, J.; Wang, J.; Yu, H.; Xiao, A. Temperature-and pH-responsive star amphiphilic block copolymer prepared by a combining strategy of ring-opening polymerization and reversible addition-fragmentation transfer polymerization. Eur. Polym. J. 2010, 46, 1288-1298. [CrossRef]

157. Xu, D.; Asai, D.; Chilkoti, A.; Craig, S.L. Rheological properties of cysteine-containing elastin-like polypeptide solutions and hydrogels. Biomacromolecules 2012, 13, 2315-2321. [CrossRef]

158. Yin, R.; Wang, K.; Du, S.; Chen, L.; Nie, J.; Zhang, W. Design of genipin-crosslinked microgels from concanavalin A and glucosyloxyethyl acrylated chitosan for glucose-responsive insulin delivery. Carbohydr. Polym. 2014, 103, 369-376. [CrossRef]

159. Chen, M.; Huang, C.; He, C.; Zhu, W.; Xu, Y.; Lu, Y. A glucose-responsive controlled release system using glucose oxidase-gated mesoporous silica nanocontainers. Chem. Commun. 2012, 48, 9522-9524. [CrossRef] [PubMed]

160. Zhao, W.; Zhang, H.; He, Q.; Li, Y.; Gu, J.; Li, L.; Li, H.; Shi, J. A glucose-responsive controlled release of insulin system based on enzyme multilayers-coated mesoporous silica particles. Chem. Commun. 2011, 47, 9459-9461. [CrossRef] [PubMed]

161. Yan, C.; Altunbas, A.; Yucel, T.; Nagarkar, R.P.; Schneider, J.P.; Pochan, D.J. Injectable solid hydrogel: Mechanism of shear-thinning and immediate recovery of injectable $\beta$-hairpin peptide hydrogels. Soft Matter 2010, 6, 5143-5156. [CrossRef] [PubMed]

162. Wang, Q.; Wang, L.; Detamore, M.S.; Berkland, C. Biodegradable colloidal gels as moldable tissue engineering scaffolds. Adv. Mater. 2008, 20, 236-239. [CrossRef]

163. Żołek-Tryznowska, Z. 6-Rheology of Printing Inks. Print. Polym. William Andrew Publ. 2016, 87-99. [CrossRef]

164. Azimi, B.; Milazzo, M.; Lazzeri, A.; Berrettini, S.; Uddin, M.J.; Qin, Z.; Buehler, M.J.; Danti, S. Electrospinning Piezoelectric Fibers for Biocompatible Devices. Adv. Healthc. Mater. 2019. [CrossRef] [PubMed]

165. Fukada, E. Piezoelectricity of biopolymers. Biorheology 1995, 32, 593-609. [CrossRef]

166. Mota, C.; Labardi, M.; Trombi, L.; Astolfi, L.; D'Acunto, M.; Puppi, D.; Gallone, G.; Chiellini, F.; Berrettini, S.; Bruschini, L.; et al. Design, fabrication and characterization of composite piezoelectric ultrafine fibers for cochlear stimulation. Mater. Des. 2017, 122, 206-219. [CrossRef]

167. Danti, S.; Azimi, B.; Candito, M.; Fusco, A.; Sorayani Bafqi, M.S.; Ricci, C.; Milazzo, M.; Cristallini, C.; Latifi, M.; Donnarumma, G.; et al. Lithium niobate nanoparticles as biofunctional interface material for inner ear devices. Biointerphases 2020, 15, 31004. [CrossRef]

168. Azimi, B.; Sorayani Bafqi, M.S.; Fusco, A.; Ricci, C.; Gallone, G.; Bagherzadeh, R.; Donnarumma, G.; Uddin, M.J.; Latifi, M.; Lazzeri, A.; et al. Electrospun ZnO/poly (vinylidene fluoride-trifluoroethylene) scaffolds for lung tissue engineering. Tissue Eng. Part A 2020. [CrossRef]

169. Chowdhury, A.R.; Abdullah, A.M.; Hussain, I.; Lopez, J.; Cantu, D.; Gupta, S.K.; Mao, Y.; Danti, S.; Uddin, M.J. Lithium doped zinc oxide based flexible piezoelectric-triboelectric hybrid nanogenerator. Nano Energy 2019, 61, 327-336. [CrossRef]

170. Chowdhury, A.R.; Jaksik, J.; Hussain, I.; Tran, P.; Danti, S.; Uddin, M.J. Surface Modified Nanostructured Piezoelectric Device as Cost-Effective Transducer for Energy and Biomedicine. Energy Technol. 2018. [CrossRef] 
171. Bodkhe, S.; Turcot, G.; Gosselin, F.P.; Therriault, D. One-step solvent evaporation-assisted 3D printing of piezoelectric PVDF nanocomposite structures. ACS Appl. Mater. Interfaces 2017, 9, 20833-20842. [CrossRef] [PubMed]

172. Chakraborty, P.; Zhou, C.; Chung, D.D.L. Piezoelectric behavior of three-dimensionally printed acrylate polymer without filler or poling. J. Mater. Sci. 2018, 53, 6819-6830. [CrossRef]

173. Chen, Z.; Song, X.; Lei, L.; Chen, X.; Fei, C.; Chiu, C.T.; Qian, X.; Ma, T.; Yang, Y.; Shung, K.; et al. 3D printing of piezoelectric element for energy focusing and ultrasonic sensing. Nano Energy 2016, 27, 78-86. [CrossRef]

174. Egunov, A.I.; Korvink, J.G.; Luchnikov, V.A. Polydimethylsiloxane bilayer films with an embedded spontaneous curvature. Soft Matter 2016, 12, 45-52. [CrossRef]

175. Kim, J.; Lee, J.H.; Ryu, H.; Lee, J.-H.; Khan, U.; Kim, H.; Kwak, S.S.; Kim, S.-W. High-Performance Piezoelectric, Pyroelectric, and Triboelectric Nanogenerators Based on P (VDF-TrFE) with Controlled Crystallinity and Dipole Alignment. Adv. Funct. Mater. 2017, 27, 1700702. [CrossRef]

176. Kim, K.; Zhu, W.; Qu, X.; Aaronson, C.; McCall, W.R.; Chen, S.; Sirbuly, D.J. 3D optical printing of piezoelectric nanoparticle-polymer composite materials. ACS Nano 2014, 8, 9799-9806. [CrossRef]

177. Ge, Q.; Dunn, C.K.; Qi, H.J.; Dunn, M.L. Active origami by 4D printing. Smart Mater. Struct. 2014, $23,94007$. [CrossRef]

178. Ge, Q.; Qi, H.J.; Dunn, M.L. Active materials by four-dimension printing. Appl. Phys. Lett. 2013, $103,131901$. [CrossRef]

179. Kim, H.; Torres, F.; Villagran, D.; Stewart, C.; Lin, Y.; Tseng, T.-L.B. 3D printing of BaTiO3/PVDF composites with electric in situ poling for pressure sensor applications. Macromol. Mater. Eng. 2017, 302, 1700229. [CrossRef]

180. Kuang, X.; Roach, D.J.; Wu, J.; Hamel, C.M.; Ding, Z.; Wang, T.; Dunn, M.L.; Qi, H.J. Advances in 4D printing: Materials and applications. Adv. Funct. Mater. 2019, 29, 1805290. [CrossRef]

181. Joshi, S.; Rawat, K.; Karunakaran, C.; Rajamohan, V.; Mathew, A.T.; Koziol, K.; Thakur, V.K.; Balan, A.S.S. 4D printing of materials for the future: Opportunities and challenges. Appl. Mater. Today 2020, 18, 100490. [CrossRef]

182. Chu, H.; Yang, W.; Sun, L.; Cai, S.; Yang, R.; Liang, W.; Yu, H.; Liu, L. 4D Printing: A Review on Recent Progresses. Micromachines 2020, 11, 796. [CrossRef]

183. Wan, X.; Luo, L.; Liu, Y.; Leng, J. Direct Ink Writing Based 4D Printing of Materials and Their Applications. Adv. Sci. 2020, 7, 2001000. [CrossRef]

184. Wan, Z.; Zhang, P.; Liu, Y.; Lv, L.; Zhou, Y. Four-dimensional bioprinting: Current developments and applications in bone tissue engineering. Acta Biomater. 2020, 101, 26-42. [CrossRef]

185. Yang, Q.; Gao, B.; Xu, F. Recent advances in 4D bioprinting. Biotechnol. J. 2020, 15, 1900086. [CrossRef]

186. Lui, Y.S.; Sow, W.T.; Tan, L.P.; Wu, Y.; Lai, Y.; Li, H. 4D printing and stimuli-responsive materials in biomedical aspects. Acta Biomater. 2019, 92, 19-36. [CrossRef]

187. Wong, K.V.; Hernandez, A. A review of additive manufacturing. ISRN Mech. Eng. 2012, 1, 1-10. [CrossRef]

188. Apsite, I.; Constante, G.; Dulle, M.; Vogt, L.; Caspari, A.; Boccaccini, A.R.; Synytska, A.; Salehi, S.; Ionov, L. $4 \mathrm{D}$ biofabrication of fibrous artificial nerve graft for neuron regeneration. Biofabrication 2020, 12, 035027. [CrossRef]

189. Apsite, I.; Uribe, J.M.; Posada, A.F.; Rosenfeldt, S.; Salehi, S.; Ionov, L. 4D biofabrication of skeletal muscle microtissues. Biofabrication 2019, 12, 15016. [CrossRef] [PubMed]

190. He, Y.; Yang, F.; Zhao, H.; Gao, Q.; Xia, B.; Fu, J. Research on the printability of hydrogels in 3D bioprinting. Sci. Rep. 2016, 6, 29977. [CrossRef] [PubMed]

191. Cholleti, E.R. A Review on 3D printing of piezoelectric materials. In Proceedings of the IOP Conference Series: Materials Science and Engineering, Istanbul, Turkey, 20-24 June 2018; pp. 455-473.

192. Cui, H.; Hensleigh, R.; Yao, D.; Maurya, D.; Kumar, P.; Kang, M.G.; Priya, S.; Zheng, X.R. Three-dimensional printing of piezoelectric materials with designed anisotropy and directional response. Nat. Mater. 2019, 18, 234-241. [CrossRef] [PubMed]

193. Chen, X.; Ware, H.O.T.; Baker, E.; Chu, W.; Hu, J.; Sun, C. The development of an all-polymer-based piezoelectric photocurable resin for additive manufacturing. Procedia CIRP 2017, 65, 157-162. [CrossRef]

194. Lee, S.C.; Gillispie, G.; Prim, P.; Lee, S.J. Physical and Chemical Factors Influencing the Printability of Hydrogel-based Extrusion Bioinks. Chem. Rev. 2020, 120, 10834-10886. [CrossRef] 
195. Naghieh, S.; Sarker, M.D.; Sharma, N.K.; Barhoumi, Z.; Chen, X. Printability of 3D printed hydrogel scaffolds: Influence of hydrogel composition and printing parameters. Appl. Sci. 2020, 10, 292. [CrossRef]

196. Boularaoui, S.; Al Hussein, G.; Khan, K.A.; Christoforou, N.; Stefanini, C. An overview of extrusion-based bioprinting with a focus on induced shear stress and its effect on cell viability. Bioprinting 2020, 20, e00093. [CrossRef]

197. Zhang, J.; Yun, S.; Karami, A.; Jing, B.; Zannettino, A.; Du, Y.; Zhang, H. 3D printing of a thermosensitive hydrogel for skin tissue engineering: A proof of concept study. Bioprinting 2020, e00089. [CrossRef]

198. Celikkin, N.; Simó Padial, J.; Costantini, M.; Hendrikse, H.; Cohn, R.; Wilson, C.J.; Rowan, A.E.; Święszkowski, W. 3D printing of thermoresponsive polyisocyanide (PIC) hydrogels as bioink and fugitive material for tissue engineering. Polymers (Basel) 2018, 10, 555. [CrossRef]

199. Sossou, G.; Demoly, F.; Belkebir, H.; Qi, H.J.; Gomes, S.; Montavon, G. Design for 4D printing: Modeling and computation of smart materials distributions. Mater. Des. 2019, 181, 108074. [CrossRef]

200. Medeiros, S.F.; Santos, A.M.; Fessi, H.; Elaissari, A. Stimuli-responsive magnetic particles for biomedical applications. Int. J. Pharm. 2011, 403, 139-161. [CrossRef] [PubMed]

201. Villar, G.; Heron, A.J.; Bayley, H. Formation of droplet networks that function in aqueous environments. Nat. Nanotechnol. 2011, 6, 803-808. [CrossRef] [PubMed]

202. Kirillova, A.; Maxson, R.; Stoychev, G.; Gomillion, C.T.; Ionov, L. 4D biofabrication using shape-morphing hydrogels. Adv. Mater. 2017, 29, 1703443. [CrossRef] [PubMed]

203. Apsite, I.; Stoychev, G.; Zhang, W.; Jehnichen, D.; Xie, J.; Ionov, L. Porous stimuli-responsive self-folding electrospun mats for 4D biofabrication. Biomacromolecules 2017, 18, 3178-3184. [CrossRef]

204. Ye, C.; Nikolov, S.V.; Calabrese, R.; Dindar, A.; Alexeev, A.; Kippelen, B.; Kaplan, D.L.; Tsukruk, V.V. Self-(Un) rolling Biopolymer Microstructures: Rings, Tubules, and Helical Tubules from the Same Material. Angew. Chem. 2015, 127, 8610-8613. [CrossRef]

205. Huang, Y.; Fitzpatrick, V.; Zheng, N.; Cheng, R.; Huang, H.; Ghezzi, C.; Kaplan, D.L.; Yang, C. Self-Folding 3D Silk Biomaterial Rolls to Facilitate Axon and Bone Regeneration. Adv. Healthc. Mater. 2020, 9, 2000530. [CrossRef]

206. Kumar, A.; Han, S.S. Emergence of bioprinting in tissue engineering: A mini review. Adv. Tissue Eng. Regen. Med. 2016, 1, 13. [CrossRef]

207. Dababneh, A.B.; Ozbolat, I.T. Bioprinting technology: A current state-of-the-art review. J. Manuf. Sci. Eng. 2014, 136. [CrossRef]

Publisher's Note: MDPI stays neutral with regard to jurisdictional claims in published maps and institutional affiliations.

(C) 2020 by the authors. Licensee MDPI, Basel, Switzerland. This article is an open access article distributed under the terms and conditions of the Creative Commons Attribution (CC BY) license (http://creativecommons.org/licenses/by/4.0/). 